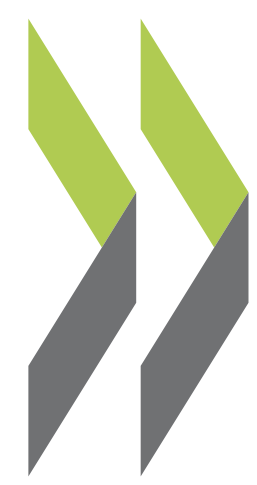

OECD Working Papers on Finance, Insurance and Private Pensions No. 36

\title{
Institutional Investors and Infrastructure Financing
}

\section{Raffaele Della Croce,}

\section{Juan Yermo}




\section{OECD WORKING PAPERS ON FINANCE, INSURANCE AND PRIVATE PENSIONS}

OECD Working Papers on Finance, Insurance and Private Pensions provide timely analysis and background on industry developments, structural issues, and public policy in the financial sector, including insurance and private pensions. Topics include risk management, governance, investments, benefit protection, and financial education. These studies are prepared for dissemination in order to stimulate wider discussion and further analysis and obtain feedback from interested audiences.

The papers are generally available only in their original language, English or French, with a summary in the other if available.

\section{OECD WORKING PAPERS ON FINANCE,} INSURANCE AND PRIVATE PENSIONS

are published on www.oecd.org/daf/fin/wp

This document and any map included herein are without prejudice to the status of or sovereignty over any territory, to the delimitation of international frontiers and boundaries and to the name of any territory, city or area.

Ce document et toute carte qu'il peut comprendre ne préjugent en rien du statut de tout territoire, de la souveraineté s'exerçant sur ce dernier, du tracé des frontières et limites internationales, et du nom de tout territoire, ville ou région.

(C) OECD 2013

Applications for permission to reproduce or translate all or part of this material should be made to: OECD Publishing, rights@oecd.org or by fax 33145249930. 


\section{ABSTRACT / RÉSUMÉ \\ INSTITUTIONAL INVESTORS AND INFRASTRUCTURE FINANCING}

The economic downturn is likely to have a lasting impact on the fund management industry and on long term asset allocation strategies of institutional investors. On one hand, in promoting more cautious investment strategies and a greater focus on portfolio risk management in the coming years. On the other hand, the prolonged low-yield environment has heightened the need for return-enhancing strategies, pushing some investors to invest in alternative assets. More fundamentally, the role of institutional investors in long term financing is constrained by the short-termism increasingly pervasive in capital markets as well as structural and policy barriers such as regulatory disincentives, lack of appropriate financing vehicles, limited investment and risk management expertise, transparency, viability issues and a lack of appropriate data and investment benchmarks for illiquid assets such as infrastructure.

JEL codes: G15, G18, G23, G28, H54, J26

Keywords: pension funds, institutional investors, asset allocation, pension regulation, infrastructure, infrastructure investment, infrastructure policy, private finance

\section{LES INVESTISSEURS INSTITUTIONNELS ET LE FINANCEMENT DES INFRASTRUCTURES}

La récession économique aura probablement un impact durable sur le secteur de la gestion de fonds et les stratégies d'allocation d'actifs à long terme des investisseurs institutionnels. D'une part, parce qu'elle met en valeur des stratégies d'investissement plus prudentes et conduit à apporter une attention plus grande à la gestion du risque de portefeuille au cours des prochaines années. D'autre part, parce que dans un contexte de faiblesse persistante des rendements, les investisseurs sont incités à adopter des stratégies plus rémunératrices et à investir dans d'autres catégories d'actifs. Plus fondamentalement, le rôle des investisseurs institutionnels dans le financement à long terme pâtit de la prédilection pour le court terme qui se généralise sur les marchés financiers, mais également des obstacles structurels et politiques, comme les réglementations dissuasives, l'absence de formules d'investissement adaptées, des compétences limitées en gestion du risque et des investissements, des questions de transparence et de viabilité des investissements et l'absence de points de référence, en termes de données et d'investissements, en ce qui concerne des actifs aussi peu liquides que les infrastructures.

Codes JEL : G15, G18, G23, G28, H54, J26

Mots clés : fonds de pension, investisseurs institutionnels, allocation d'actifs, réglementation des pensions, infrastructures, investissement en infrastructures, politique des infrastructures, financement privé 


\section{ACKNOWLEDGEMENTS}

This OECD Working Paper was prepared by Raffaele Della Croce and Juan Yermo, with statistical support from Jean-Marc Salou and Romain Despalins from the OECD Directorate for Financial and Enterprise Affairs.

The authors would like to thank the following expert reviewers for their input and comments on Section 3 of this report: Andreas Kappeler (OECD Economics Department) and Christopher Kaminker (OECD Environment Directorate), Stephen Perkins (International Transport Forum), Anthony Sykes (SMBC), Julien Touati (Meridiam), Georg Grodzky (Legal \& General), Felicita Gimenez (Dealogic), Eva Romer (European Commission), Elliot Bradbrook (Preqin), Claudia Kapp (InRev), John Kjorstad and Yoann Rey (Infrastructure Journal).

The authors would also like to thank partners of the OECD Project on Institutional Investors and Long-Term Investment for their support: the Canadian pension fund CPPIB, the Club of Long Term Investors, the Dutch pension fund APG, Guggenheim Partners and Oliver Wyman (www.oecd.org/finance/lti).

This working paper is part of the OECD report "The Role of Banks, Equity Markets and Institutional Investors in Long Term Financing for Growth and Development" presented at the Meeting of the G20 Finance Ministers and Central Banks Governors on 15-16 February 2013 in Moscow. At this meeting G20 leaders agreed to establish a Study Group on Financing for Investment with the co-operation of international organizations. The findings of this paper contributed to the work of the Study Group. 


\section{TABLE OF CONTENTS}

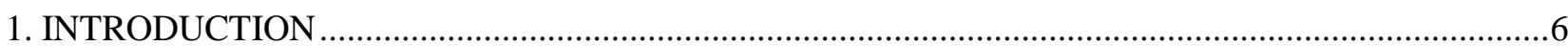

2. THE ROLE OF INSTITUTIONAL INVESTORS IN LONG-TERM FINANCING ................................

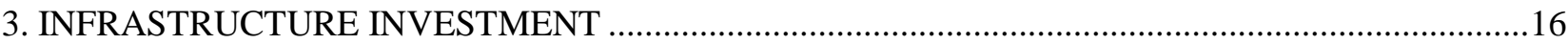

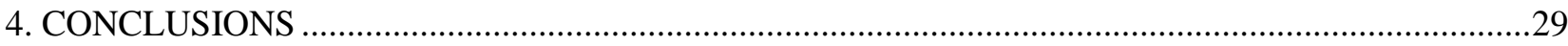

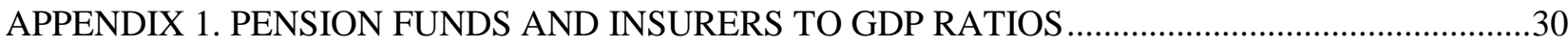

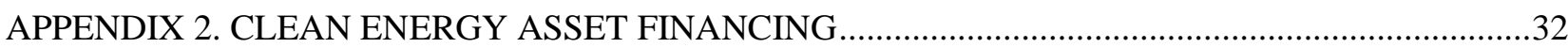

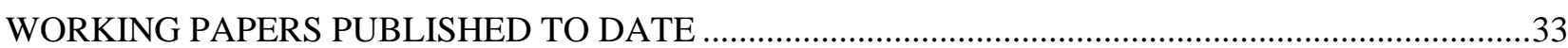

\section{Tables}

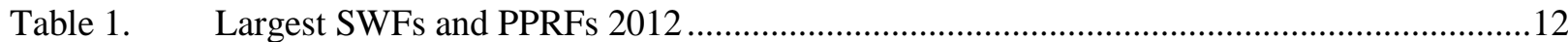

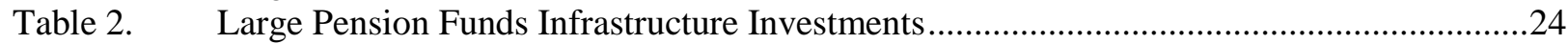

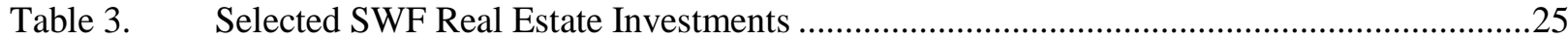

\section{Figures}

Figure 1. Total assets by type of institutional investors in the OECD, 1995-2011 ..........................

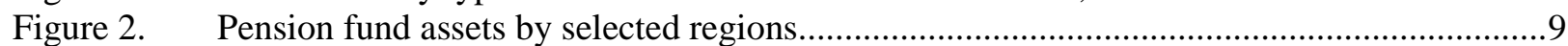

Figure 3. Asset Allocation of Pension funds and Insurers in selected OECD countries, 2011 ..........10

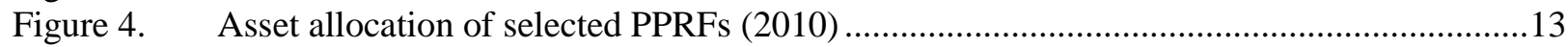

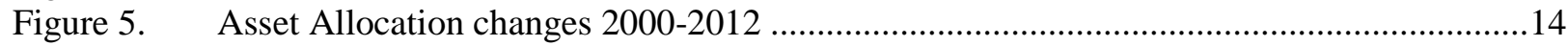

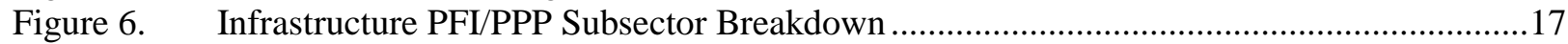

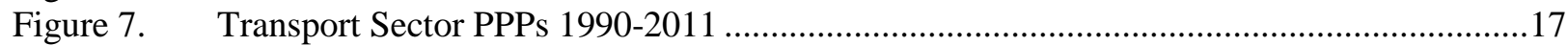

Figure 8. Project Finance Global Volume by Region, 2005-2012 …............................................19

Figure 9. Global Project Finance Volume \$Bn ..............................................................................19

Figure 10. Infrastructure fundraising (amounts and number of funds) ……....................................20

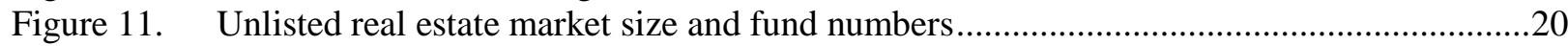

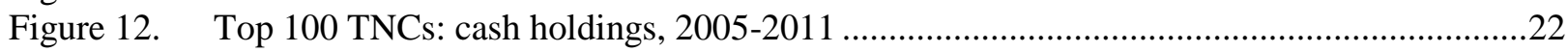

Figure 13. Countries with highest pension fund to GDP ratios among the reporting OECD

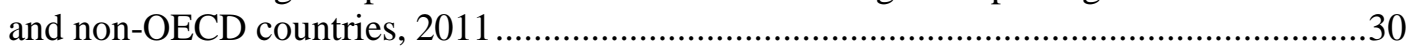

Figure 14. Countries with highest insurers to GDP ratios among the reporting OECD

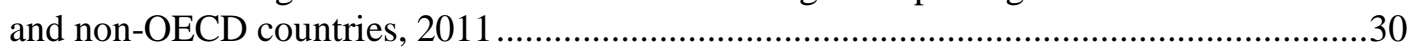

Figure 15. Foreign investment of pension funds in selected OECD countries, 2011 ........................31

Figure 16. Clean energy asset financing where pension funds (left) and insurance companies (right).

\section{Boxes}

Box 1. PPPs and Regulatory Asset Based Models for Investment in Transport Infrastructure .................17

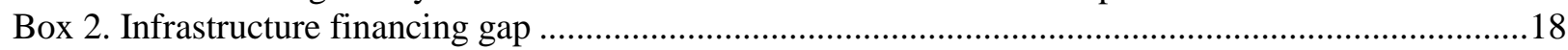

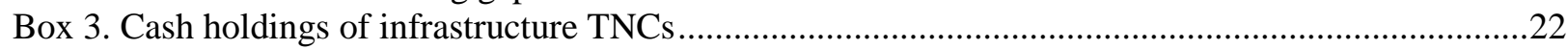

Box 4. Examples of Insurance Companies' Investments in Clean Energy Projects ..................................26 


\title{
INSTITUTIONAL INVESTORS AND INFRASTRUCTURE FINANCING
}

\author{
By Raffaele Della Croce and Juan Yermo*
}

\section{INTRODUCTION}

This working paper is part of the OECD report "The Role of Banks, Equity Markets and Institutional Investors in Long Term Financing for Growth and Development" presented at the Meeting of the G20 Finance Ministers and Central Banks Governors on 15-16 February 2013 in Moscow. At this meeting G20 leaders agreed to establish a Study Group on Financing for Investment with the co-operation of international organizations. The findings of this paper contributed to the work of the Study Group. OECD Report to G20 Leaders

The financial sector plays an essential role in providing and channeling financing for investment. Beyond providing short-term finance for businesses' day-to-day operations and other temporary cash requirements, financial institutions, capital markets and institutional investors are also sources of long-term finance that is finance which is available for an extended period of time ${ }^{I}$.

The importance of long-term finance lies in its pivotal role in satisfying long-term physical investment needs across all sectors in the economy and specifically in key drivers of growth, competitiveness and employment such as the infrastructure, real estate, $R \& D$ and new ventures.

Traditionally, banks have been a key player in the financial system, transforming savings into long-term capital to finance private sector investment. Over time, two main changes have taken place in the structure of the financial system. First, the banking model has evolved, becoming increasingly dominated by wholesale markets and in particular derivatives, to the detriment of the more traditional deposit-taking and lending activities. Second, disintermediation and the growth of capital markets has led to a shift in the structure of the financial sector, with institutional investors such as pension funds, insurance companies,

\footnotetext{
* This working paper was prepared by Raffaele Della Croce and Juan Yermo, with statistical support from Jean-Marc Salou and Romain Despalins from the OECD's Directorate for Financial and Enterprise Affair. This report is published under the responsibility of the OECD Secretary General. The views contained herein may not necessarily reflect those of the OECD Members.

${ }^{1}$ For the purposes of the G20 note, "long-term" has been defined as maturities of at least five years. It also refers to sources of financing that have no specific maturity but are generally relatively stable over time. The OECD has recently launched a project on Long Term Investment (www.oecd.org/finance/lti), identifying a set of criteria for long-term investment by institutional investors:

- $\quad$ productive capital, providing support for infrastructure development, green growth initiatives, SME finance etc., leading to sustainable growth;

- $\quad$ patient capital allowing investors to access illiquidity premia, lowers turnover, encourages less pro-cyclical investment strategies and therefore higher net investment rate of returns and greater financial stability;

- $\quad$ engaged capital which encourages active voting policies, leading to better corporate governance.
} 
mutual funds, and, most recently, sovereign wealth funds, also becoming central players as providers of long-term capital.

After the financial crisis, the traditional sources of investment financing are all facing challenges - whether it be fiscal constraints on government spending, or the weak economic outlook not proving conducive to corporate investment (with implications for both the debt and equity markets), with the main blockages to investment remaining in the banking sector.

Structural weaknesses in the banking sector are leading to 'bad' deleveraging, particularly in Europe, in the form of restrained credit growth ${ }^{2}$. This is causing a growing mismatch between the amount and time horizon of available capital and the demand for long-term finance. New banking regulations (Basle III) could also affect negatively the ability of banks to provide long-term financing. The emerging long-term financing gap is particularly acute in the infrastructure sector and could slow down the world economy for years to come and abort attempts by emerging and developing economies (EMDEs) to set themselves on a high-growth path.

With over USD 70 trillion in assets, institutional investors (such as pension funds and insurance companies) are frequently cited as an alternative source of financing. Given the low interest rate environment and volatile stock markets of recent years, institutional investors are increasingly looking for new sources of long-term, inflation protected returns. Investments in real, productive assets, such as infrastructure could potentially provide the type of income which these investors require supporting investment and driving growth. However, there are also major challenges to higher allocations to such assets, from the small size of many pension funds and insurers to regulatory barriers.

This note seeks to identify the main trends in long-term financial intermediation focusing on the role of institutional investors in providing long-term finance for growth and development. It also highlights infrastructure as one specific sector that is facing major challenges in long-term financing. Section 1 introduces, Section 2 discusses the evolution of investment strategies among institutional investors Section 3 looks at infrastructure financing and the challenges institutional investors face to invest in infrastructure. The last section concludes.

\footnotetext{
${ }^{2}$ See Blundell-Wignall, A. and P. Atkinson (2012), "Deleveraging, Traditional versus Capital Markets Banking and the Urgent Need to Separate and recapitalize G-SIFI Banks", OECD Journal, Financial Market Trends, Issue 1, No. 102.
} 


\section{THE ROLE OF INSTITUTIONAL INVESTORS IN LONG-TERM FINANCING}

\subsection{Global Asset Allocations}

Institutional investors, particularly, pension funds, insurance companies, and mutual funds are an increasingly important player in financial markets. In OECD countries alone, these institutions held over USD 70 trillion euros in assets by December 2011 (see Figure 1), over 40\% of which is accounted for by institutions based in the United States. The annual inflow of new funds is also substantial. For instance, pension funds collected about USD 1 trillion in new contributions in 2011. Also growing rapidly are Sovereign Wealth Funds (SWFs) and Public Pension Reserve Funds (PPRFs).

Figure 1. Total assets by type of institutional investors in the OECD, 1995-2011 (in trillion USD)

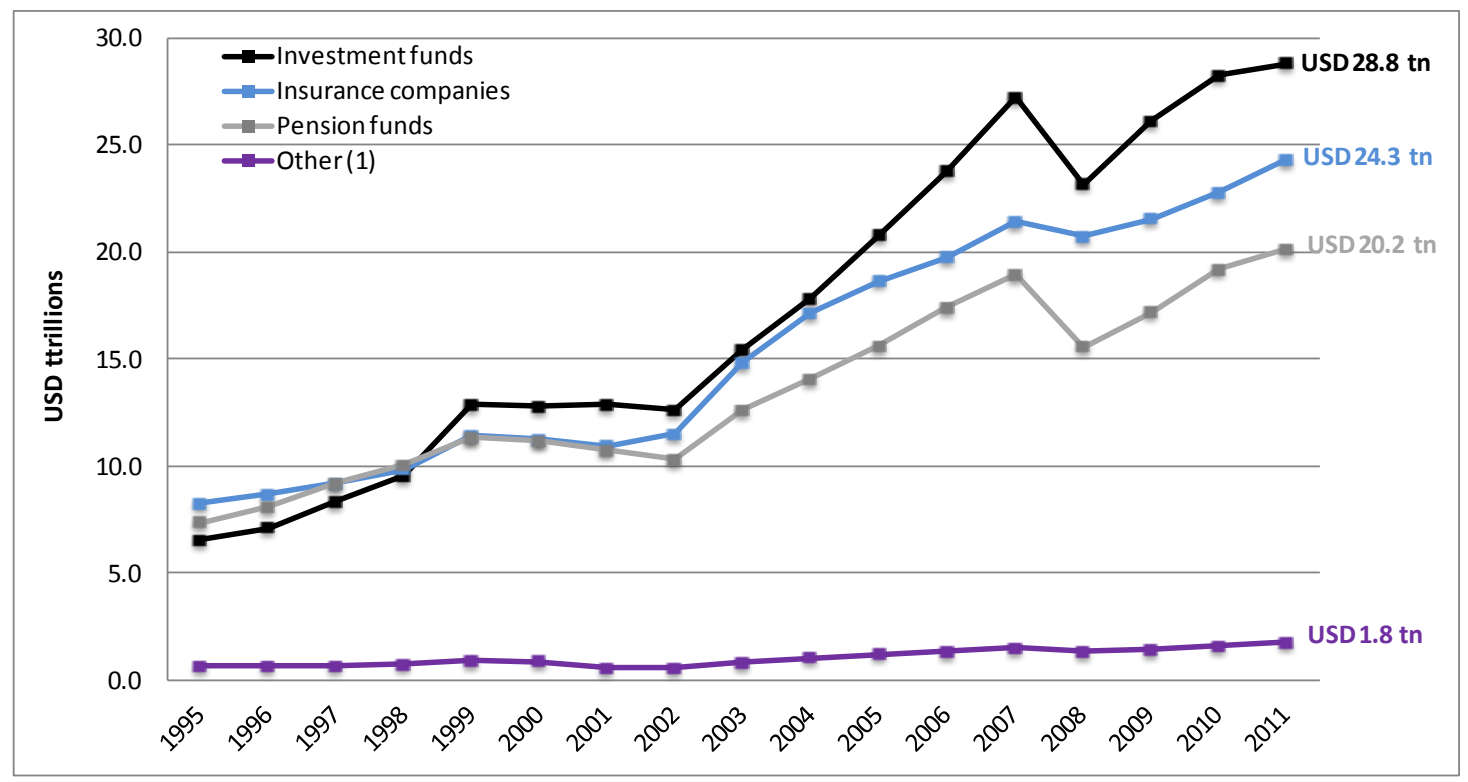

Source: OECD Global Pension Statistics, Global Insurance Statistics and Institutional Investors databases, and OECD estimates. Note: This chart was prepared with data available on 18 December 2012. Book reserves are not included in this chart. Pension funds and insurance companies' assets include assets invested in mutual funds, which may be also counted in investment funds. 1. Other forms of institutional savings include foundations and endowment funds, non-pension fund money managed by banks, private investment partnership and other forms of institutional investors. 
Figure 2. Pension fund assets by selected regions

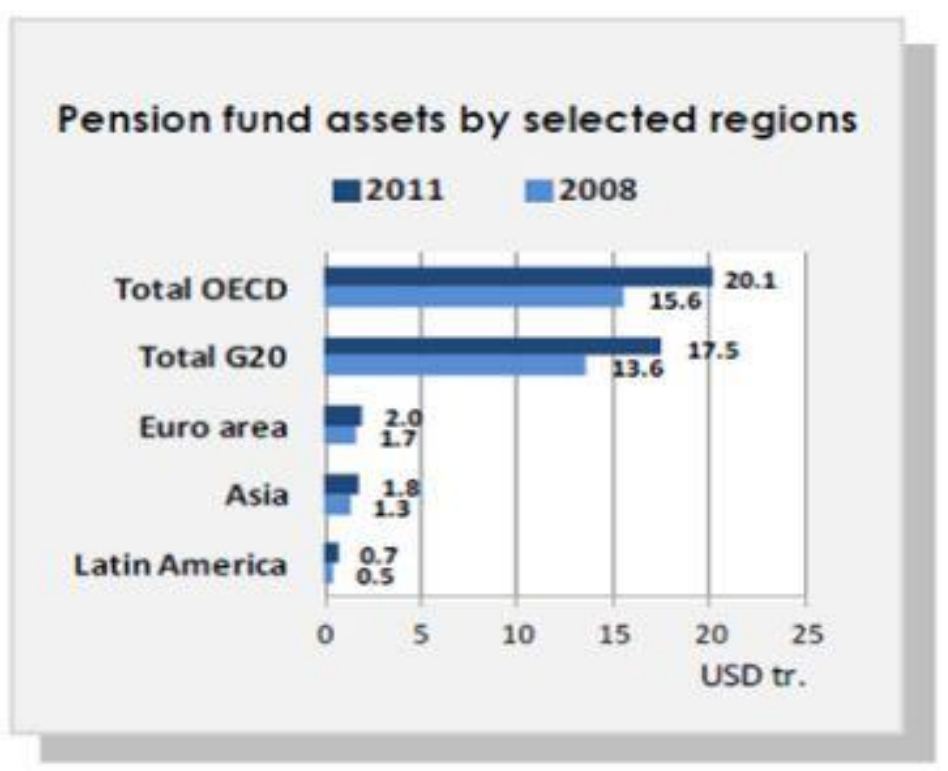

Source: OECD Pension and Insurance Statistics

The importance of institutional investors for national economies can be gauged by the size of their asset holdings relative to GDP. Pension funds and insurers are major investors in a large number of developed economies, with assets representing over $60 \%$ of GDP in countries such as Canada, the Netherlands, the United Kingdom and the United States (see Figures in Appendix). In non-OECD countries, institutional investors tend to be less developed, but there are some important exceptions such as Brazil and South Africa, which have well-developed pension fund and mutual fund industries. Among non-OECD countries, South Africa actually has one the largest pension fund industries both in absolute terms and in relation to its economy, at over 60\% of GDP, which puts it at the level of the top OECD countries.

Despite the recent financial crisis, the prospect for future growth for institutional investors is unabated, especially in countries where private pensions and insurance markets are still small in relation to the size of their economies. EMDEs generally face an even greater opportunity to develop their institutional investors' sectors as, with few exceptions, their financial systems are largely bank-based. Whether such growth materialises will depend on some key policy decisions, such as the establishment of a national pension system with a funded component which is nowadays a common feature in most OECD countries. ${ }^{3}$ Emerging economies are also home to some of the largest SWFs in the world.

\section{Portfolio Allocation}

The investment strategies of institutional investors differ significantly across countries. Asset allocation is influenced by a variety of factors, such as market trends, investment beliefs, regulation, risk appetite, liability considerations, cultural factors, governance structures, tax issues and ultimately domestically available assets.

Traditionally, institutional investors have been seen as sources of long-term capital with investment portfolios built around the two main asset classes (bonds and equities) and an investment horizon tied to

\footnotetext{
${ }^{3}$ However, owing to rising public debt, some OECD countries such as Hungary and Poland have partially rolled back reforms that had established mandatory funded pension systems.
} 
the often long-term nature of their liabilities. However, over the last decade there have been major shifts in investment strategies. In particular, there has been a marked decline in allocation to listed equities, while investment in bonds and so-called alternative assets classes has increased substantially.

Figure 3. Asset Allocation of Pension funds and Insurers in selected OECD countries, 2011 (as \% of total investment)

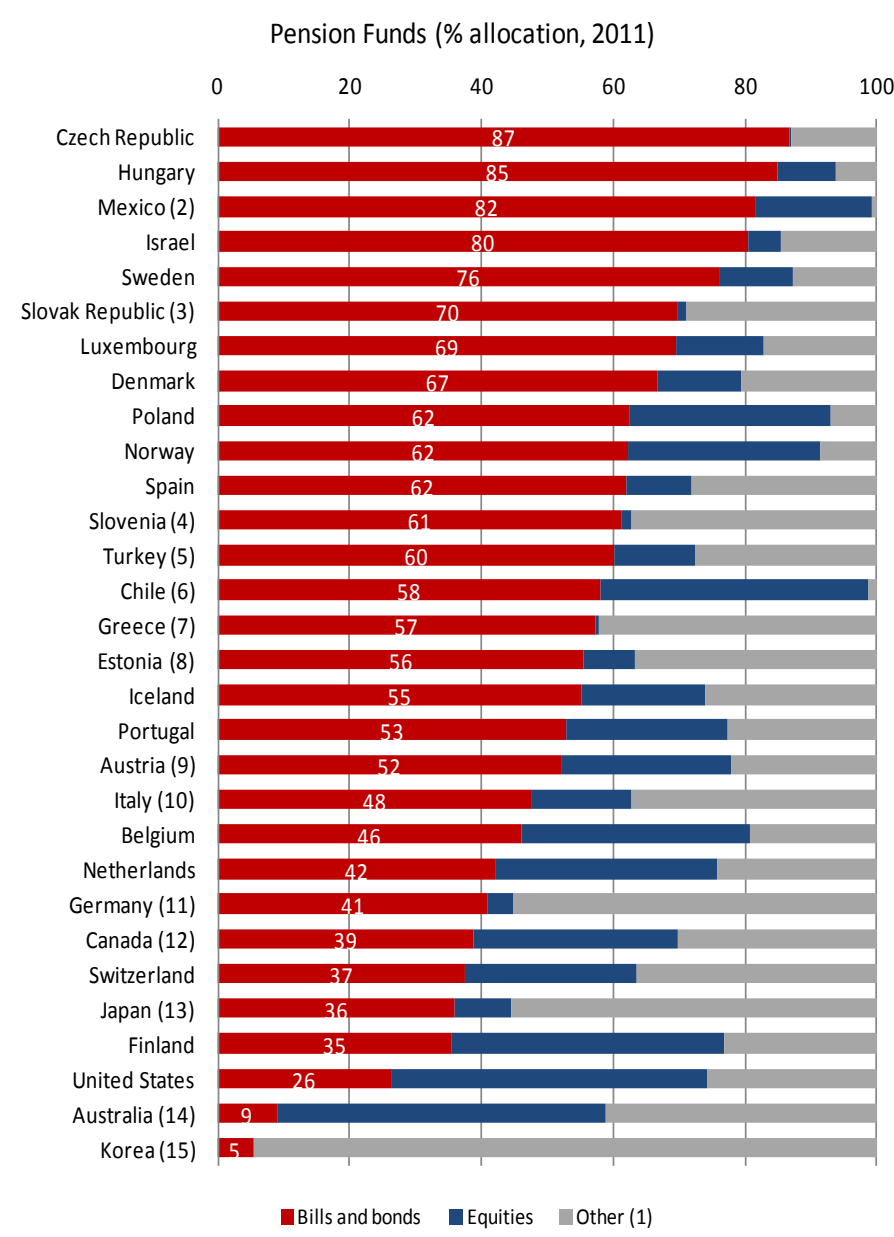

Source : OECD Pension and Insurance Statistics
Direct insurers (\% allocation, 2011)

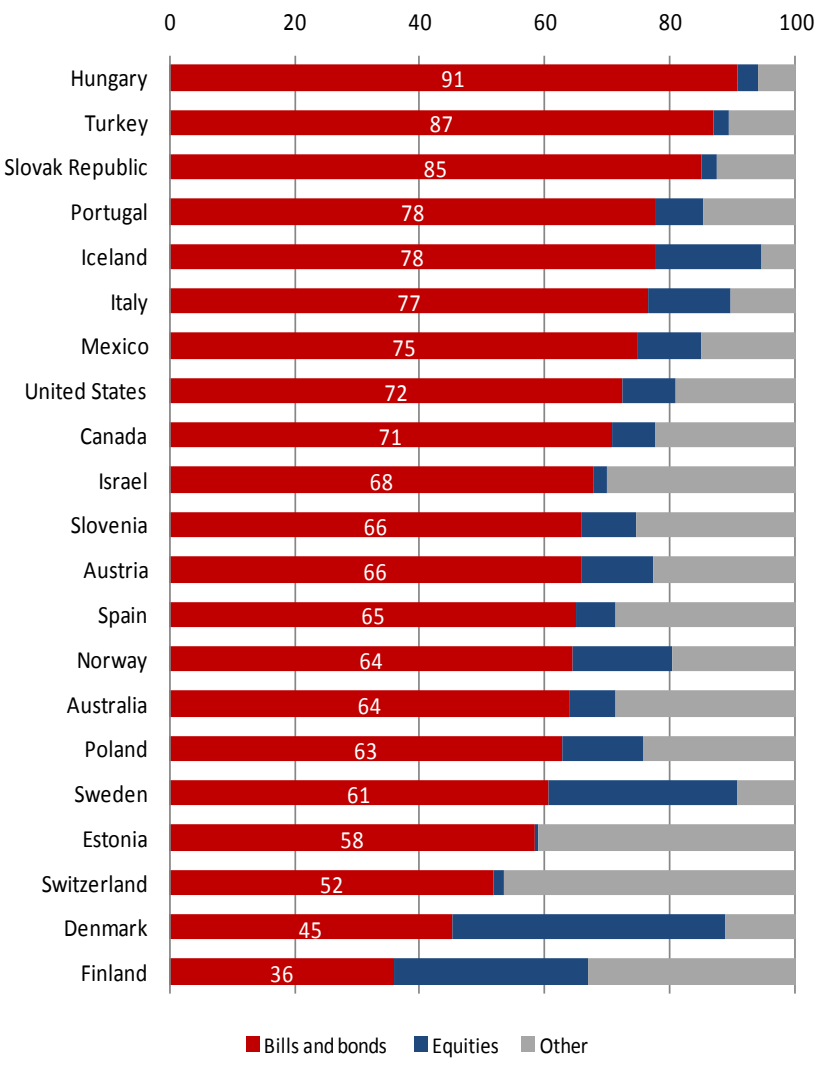




\section{Trends}

Investors' exposure to alternative assets continues to grow, extending a long-established trend and reflecting the growing appetite among pension funds for diversification, their search for yield and the attraction of valuation methods for unlisted assets. Institutional investors have been increasing allocation to alternative assets such as hedge funds, real estate, private equity and, most recently, infrastructure, including 'green infrastructure"

In addition to diversifying their portfolios into a wider range of asset classes, institutional investors have also gradually increased their international exposure over the years. Following the financial crisis, there seems also to be acceleration in the trend of investing in emerging markets, with investors expecting investment performance to track the positive economic prospects of these countries.

Looking at the level of international diversification of individual investors, some pension funds particularly large institutions in Canada and the European Union - have a high allocation to foreign equities, with exposures in some cases representing more than $80 \%$ of the total stock of equities and $60 \%$ of fixed income. On the other hand, Latin American pension funds, with the exception of the Chilean one, had very low levels of overseas investment. Similarly, South African pension funds have low allocations to foreign assets. For instance the Government Employees Pension Fund, by far the largest pension fund in the African continent, had a negligible allocation to foreign equities (less than 2\%) in 2011 and its fixed income portfolio was fully domestic.

\section{Increasing importance of $S W F$ s and PPRFs}

Sovereign Wealth Funds (SWFs) and Public Pension Reserve Funds (PPRFs) are becoming major players in international financial markets. Assets under management have been growing rapidly and in 2011 were accounting for more than USD 10 trillion in assets. ${ }^{5}$

The asset allocation of SWFs and PPRFs varies widely depending on their specific objectives and mandates. ${ }^{6}$ Funds more focused on fiscal stabilization for example have a higher weight on fixed income and cash while national saving funds and pension reserve fund $\mathrm{s}$ are more likely to have a higher allocation to equity and more riskier investment.

\footnotetext{
${ }^{4}$ For example:

a) Canadian pension fund OMERS approved an asset mix policy target in 2004 of allocating $37.5 \%$ of capital to private markets. In May 2009 the Board confirmed the decision, increasing the target allocation to private market to 47\%. OMERS has been further implementing the portfolio shift in 2010, gaining greater exposure to private markets.

b) Dutch ABP investment portfolio has been changing in the last years. The relative share of equities and alternative investments in total investments increased and that of investments in fixed-income securities fell in 2009. Other investments are investments in infrastructure and hedge fund strategies. In the context of its three-yearly review of financial policy, ABP adopted the Strategic Risk Framework in 2009 which defined that ABP will seek to achieve at least 20 per cent inflation protection, inter alia by opting for inflation-linked bonds and investments in other asset classes such as infrastructure.

c) UK fund USS is expanding the range of activity undertaken internally building up its alternative allocation ( target 20\%), with a corresponding reduction in the allocation to quoted equities.

${ }^{5}$ Based on total assets of 83 SWFs and PPRFs funds across regions (Source OECD, SWF Institute, SWFs annual reports). Although there is no widely accepted definition PPRFs can be defined as funds set up by governments or social security institutions to contribute to the financing of the relevant pay-as-you-go pension plans.

${ }^{6}$ For example, the government pension fund "global" in Norway has two main goals: to facilitate government savings necessary to meet the rapid rise in public pension expenditures in the coming years, and to support a long-term management of petroleum revenues. Russia's national wealth fund is dedicated to supporting the pension system to guarantee long-term sound functioning of the system.
} 
Table 1. Largest SWFs and PPRFs $2012^{7}$

\begin{tabular}{|c|c|c|c|c|}
\hline Country & Sovereign Wealth Fund Name & $\begin{array}{l}\text { Assets } \\
\text { \$Billion }\end{array}$ & Inception & Origin \\
\hline Norway & Government Pension Fund - Global & $\$ 664.3$ & 1990 & Oil \\
\hline UAE - Abu Dhabi & Abu Dhabi Investment Authority & $\$ 627$ & 1976 & Oil \\
\hline China & SAFE Investment Company & $\$ 567.9 * *$ & 1997 & Non-Commodity \\
\hline Saudi Arabia & SAMA Foreign Holdings & $\$ 532.8$ & $\mathrm{n} / \mathrm{a}$ & Oil \\
\hline China & $\mathrm{ClC}$ China Investment Corporation & $\$ 482$ & 2007 & Non-Commodity \\
\hline China - Hong Kong & Hong Kong Monetary Authority Inves tment Portf & $\$ 298.7$ & 1993 & Non-Commodity \\
\hline Kuwait & Kuwait Investment Authority & $\$ 296$ & 1953 & Oil \\
\hline Singapore & Government of Singapore Investment Corporati & $\$ 247.5$ & 1981 & Non-Commodity \\
\hline Singapore & Temasek Holdings & $\$ 157.5$ & 1974 & Non-Commodity \\
\hline Russia & National Weath Fund & $\$ 149.7^{*}$ & 2008 & Oil \\
\hline China & National Social Security Fund & $\$ 134.5$ & 2000 & Non-Commodity \\
\hline Qatar & Qatar Investment Authority & $\$ 115$ & 2005 & Oil \\
\hline Australia & Australian Future Fund & $\$ 83$ & 2006 & Non-Commodity \\
\hline UAE - Dubai & Investment Corporation of Dubai & $\$ 70$ & 2006 & Oil \\
\hline UAE - Abu Dhabi & International Petroleum Investment Company & $\$ 65.3$ & 1984 & Oil \\
\hline Libya & Libyan Investment Authority & $\$ 65$ & 2006 & Oil \\
\hline Kazakhstan & Kazakhstan National Fund & $\$ 61.8$ & 2000 & Oil, gas, metals \\
\hline Algeria & Revenue Regulation Fund & $\$ 56.7$ & 2000 & Oil \\
\hline UAE - Abu Dhabi & Mubadala Development Company & $\$ 53.1$ & 2002 & Oil \\
\hline South Korea & Korea Investment Corporation & $\$ 43$ & 2005 & Non-Commodity \\
\hline US - Alaska & Alaska Permanent Fund & $\$ 42.8$ & 1976 & Oil \\
\hline Iran & National Development Fund of Iran & $\$ 40$ & 2011 & Oil \& Gas \\
\hline Malaysia & Khazanah Nasional & $\$ 34$ & 1993 & Non-Commodity \\
\hline Azerbaijan & State Oil Fund & $\$ 32.7$ & 1999 & Oil \\
\hline Brunei & Brunei Investment Agency & $\$ 30$ & 1983 & Oil \\
\hline France & Strategic Investment Fund & $\$ 25.5$ & 2008 & Non-Commodity \\
\hline US - Texas & Texas Permanent School Fund & $\$ 25.5$ & 1854 & Oil \& Other \\
\hline Ireland & National Pensions Reserve Fund & $\$ 18$ & 2001 & Non-Commodity \\
\hline New Zealand & New Zealand Superannuation Fund & $\$ 16.6$ & 2003 & Non-Commodity \\
\hline Canada & Alberta's Heritage Fund & $\$ 16.4$ & 1976 & Oil \\
\hline
\end{tabular}

Source: Annual reports of SWFs, SWF Institute

Compared to other institutional investors, many PPRFs have a relative certainty of the asset base as well as amount and timing of future cash flows. For example, the Canadian Pension Plan Investment Board ("CPPIB") is not expected to use any investment income to help pay benefits until 2021. Hence, PPRFs are not forced, in theory, to seek the short-term returns that many other market participants must achieve due to their investment objectives, yield requirements or business models, nor are they driven by short-horizon market dynamics. On the other hand some PPRFs may be subject to political pressure, directly influencing their asset allocation decisions.

\footnotetext{
${ }^{7}$ If not available, 2011 figures were used.
} 
Figure 4. Asset allocation of selected PPRFs (2010)

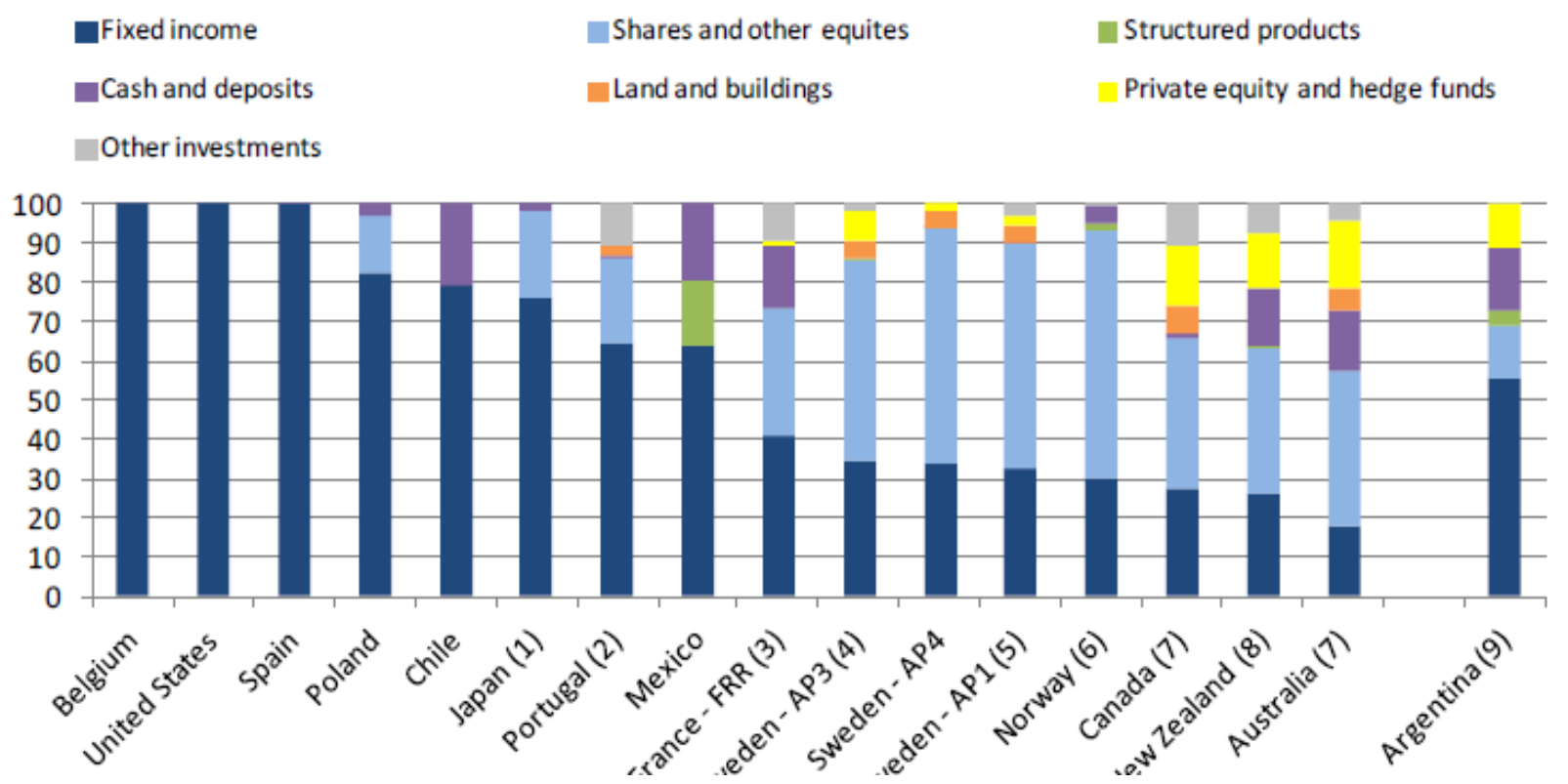

Source : OECD Pension and Insurance Statistics

Some PPRFs increased their existing allocations to non-traditional asset classes like private equity and hedge funds. For instance, the Australian Future Fund allocated $17.7 \%$ of its assets in private investment funds in 2010, from $12.7 \%$ in 2009 and $4.8 \%$ in 2008 . This share should remain stable as the fund's target allocation into alternative assets is set to $15 \%$. Some funds also started to invest in infrastructure, mainly through listed and unlisted equity. For instance, $6 \%$ of the Canadian Pension Plan's portfolio is invested in infrastructure assets via unlisted equity, and 9\% of the Swedish AP3 funds portfolio is invested in infrastructure assets via listed equity.

SWFs are also major investors in some developing countries including G20 countries such as China, Saudi Arabia and Russia. For instance, UNCTAD data shows that the rise in involvement by SWFs in international infrastructure is increasingly discernable. Cross-border M\&As in the sector by SWFs in 2011 reached $\$ 6.4$ billion, the highest level recorded to date.

\subsection{Impact of the financial crisis on investment allocations}

The economic downturn is likely to have a lasting impact on the fund management industry and on long term asset allocation strategies of institutional investors in promoting more cautious investment strategies and a greater focus on portfolio risk management in the coming years. Although it is difficult to measure investors' market sentiment there seems to be anecdotal evidence that some factors may have altered asset allocation frameworks in a structural and lasting way. In order to better understand these factors, more granular data at the level of individual investors is needed. The OECD is planning further research in the next months. 


\section{Lower risk appetite and investment consequences}

Heightened volatility and muted performance in US and European equity markets has lowered investors' risk appetite for listed equities. Investors have sought refuge in bills and bonds from governments with strong creditworthiness, the so called "safe assets". ${ }^{8}$ The financial crisis has effectively accelerated a long term trend increase of bond allocation that started at the beginning of the last decade. In addition, there is an increased demand for derisking strategies via hedging with derivative instruments. There has also been a continuation of closures, buy-outs and buy-ins of defined benefit pension plans, particularly in the United Kingdom.

Figure 5. Asset Allocation changes 2000-2012

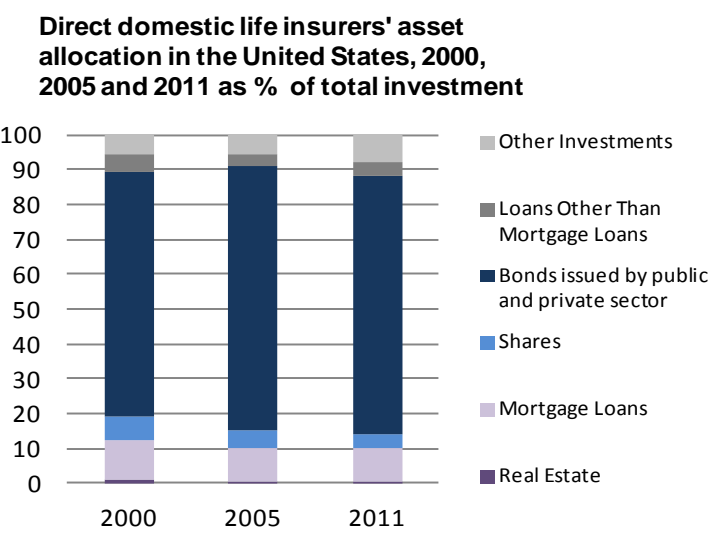

Direct domestic life insurers' asset allocation in Europe, 2000, 2005 and 2011 as \% of total investment

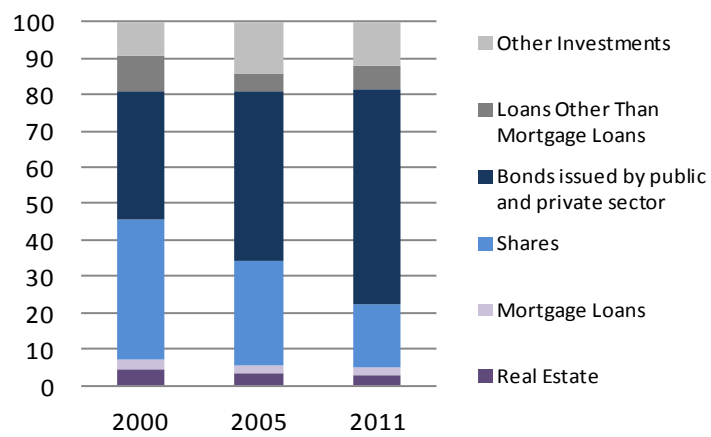

Pension Funds ' asset allocation in the United States, 2000, 2005 and 2011 as \% of total investment

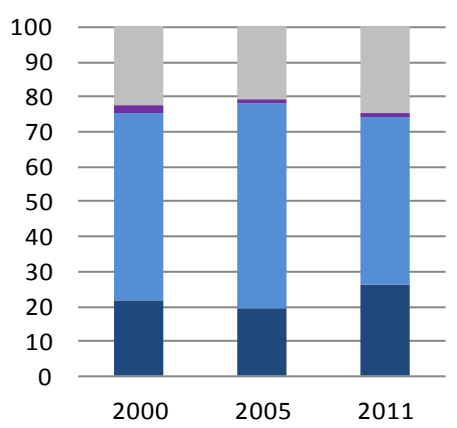

- Other (1)

Cash and Deposits

- Shares

- Bills and bonds issued by public and private sector

Pension Funds asset allocation in Europe 2000, 2005 and 2011 as \% of total investment

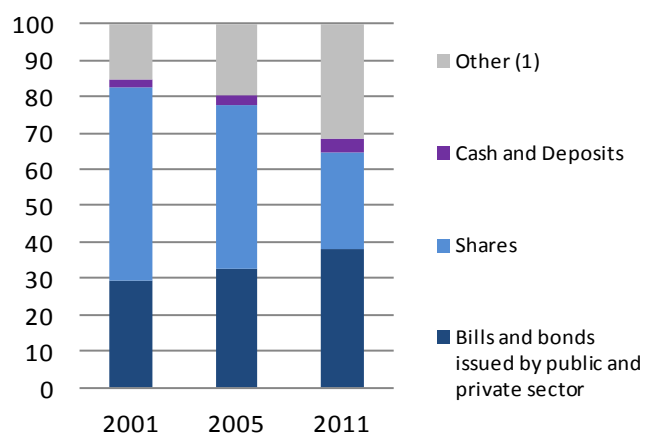

Source : OECD Pension and Insurance Statistics

The growing interest in good quality - income oriented - inflation linked investments that can match their liabilities has also been influenced by a greater appreciation of the interest sensitivity of plan liabilities and the risks of large mismatch in the characteristics of plan assets and liabilities. ${ }^{9}$

However, in some countries, there is a limited supply of debt instruments (e.g. inflation linked bonds) with maturities longer than 15 or 20 years able to accommodate increased pension sector demand ${ }^{10}$. For

\footnotetext{
${ }^{8}$ Developed market government debt is no longer considered a risk-free asset class, as large structural budget deficits weigh on both the US and Europe.

${ }^{9}$ Pension funds liabilities are sensitive over time to emerging inflation since the benefits of active employees are typically linked to their wages and retiree benefits are increased in line with some portion of price inflation but many plan sponsors.
} 
example, Scandinavian insurers face a supply constraint when increasing their government debt allocations as the region's countries are small relatively well off and do not need to issue large amounts of bonds. Pressures on bond yields and swap rates from growing institutional investor demand have also been observed in the United Kingdom and Denmark, among other countries.

\section{Low-yield environment}

Despite increased sensitivity to risk, the prolonged low-yield environment has heightened the need for return enhancing strategies pushing some investors to take on additional risk in alternative assets and in smaller, potentially less liquid markets to increase returns on their assets.

In a low interest environment expected to last for some time, institutional investors that need to earn minimum absolute return (such as insurance companies with contracted minimum guaranteed returns and underfunded pension funds) will be in particular under pressure to look for higher returns and riskier investments to deliver on their promises.

In May 2012, GSAM Insurance Asset Management conducted a Chief Investment Officer (CIO) survey across 152 insurance companies globally, representing over USD 3.8 trillion in assets. ${ }^{11}$ The results of the survey suggest that insurers are concerned about the investment environment with Europe at the forefront, with current yields resulting in lower instrument returns. The challenge is exacerbated by the longer-term potential of rising interest rates and inflation.

The study found a net third of those surveyed were planning to increase their allocations to high yield debt, roughly three in ten to property and emerging market debt, and almost a fifth to private equity. In search for yield insurers are migrating down the corporate credit quality spectrum via increasing allocations to high yield, bank loans and mezzanine debt. In addition, insurers intend to increase their allocations to such asset classes as real estate, emerging market debt and private equity. It is likely that insurers will fund movement into less liquid investments by reducing their positions in cash and short-term instruments.

\section{Impact of New Regulatory Initiatives}

The move to market-consistent valuations and risk-based solvency standards is also indirectly affecting the ability of pension funds and insurers to act as long-term investors, investing in longer-term, less liquid assets such as infrastructure and other alternative asset classes. ${ }^{12}$ The regulatory framework can also affect the ability of institutional investors to act in a patient and countercylical manner, supporting riskier and less liquid assets through market downturns.

Specifically, when discount rates are based on market interest rates and bonds have a low risk weighting in the solvency regulatory framework, there is a strong incentive to use bonds and interest rate hedging instruments to reduce volatility in solvency levels, as has been observed in the insurance and pension fund sectors in some Scandinavian countries.

\footnotetext{
${ }^{10}$ Other reasons why pension funds are struggling to implement liabilities matching is due to their state of underfunding and the high cost this strategy would imply given current low interest rates.

${ }^{11}$ Seeking return in an Adverse Environment Insurance CIO Survey GSAM INSURANCE JULY 2012

12 See "Fixed income strategies of insurance companies and pension funds" by the CGFS (July 2011, No. 44, http://www.bis.org/publ/cgfs44.pdf), "Promoting Longer-Term Investment by Institutional Investors: Selected Issues and Policies" by Della Croce et al (OECD Financial Market Trends Vol. 2011/1, http://dx.doi.org/10.1787/19952872), and "The Effect of Solvency Regulation and Accounting Standards on Long-Term Investing" by Severinson and Yermo (November 2012, OECD Working Papers on Finance, Insurance and Private Pensions No. 30, http://dx.doi.org/10.1787/5k8xd1nm3d9n-en) and the FSB report for the G20 "Financial regulatory factors affecting the availability of long-term investment finance".
} 


\section{INFRASTRUCTURE INVESTMENT}

\subsection{Private Sector Involvement in Infrastructure}

Over the last decades, public capital investment in infrastructure has on average declined in OECD countries. The OECD average ratio of capital spent in fixed investment (mainly infrastructure) to GDP fell from above $4 \%$ in 1980 to approx $3 \%$ in 2005. This reflected a decline in public investment in countries with both traditionally high and low public investment rates between the early 1980s and late 1990s, though it has subsequently stabilized.

Public provision of infrastructure has sometimes failed to deliver efficient investment with misallocation across sectors, regions or time due to political considerations. Constraints on public finance and recognized limitations on the public sector's effectiveness in managing projects have led to a reconsideration of the role of the state in infrastructure provision ${ }^{13}$.

As the share of government investment in infrastructures has declined that of private sector has increased, with privatisations being an important driver. In OECD countries alone, some USD 1 th of stateowned assets have been sold in recent decades. Out of total privatisations of around USD 900 bn since 1990, more than 550 bn $(63 \%)$ have been accounted for by infrastructure, notably utilities, transport and telecommunications ${ }^{14}$.

The greater part of the private sector's infrastructure investment is made directly by utility and transport companies. However, since the 1990s national policies of many countries have sought to increase private sector participation in the financing and implementation of infrastructure projects -especially new projects- by other complementary means, notably through "project finance"15.

New business models with private sector participation, variants of public-private partnership models (PPPs) -often using project finance technique- have been increasingly used particularly in OECD countries, offering further scope for unlocking private sector capital and expertise [See Box 1].

\footnotetext{
${ }^{13}$ The state changes its role from owner and provider of public services to purchaser and regulator of them. The private sector comes in as financier and manager of infrastructure expecting attractive returns.

${ }^{14}$ Data from the OECD Privatisation Database, and The Privatization Barometer.

${ }^{15}$ As pointed out by Yescombe the growth and spread of PPPs around the world is closely linked to the development of project finance, a financial technique based on lending against the cash flow of a project that is legally and economically self-contained. Project finance arrangements are highly leveraged and lenders receive no guarantees beyond the right to be paid from the cash flows of the project. Moreover as the assets of the project are specific, they are illiquid and have little value if the project is a failure.
} 


\section{Box 1. PPPs and Regulatory Asset Based Models for Investment in Transport Infrastructure ${ }^{16}$}

Governments are increasingly turning to PPPs for investment in public infrastructure. The largest share of such investment to date has been in transport and mainly in advanced countries although PPPs are also widespread in middle income and developing countries (figure below).

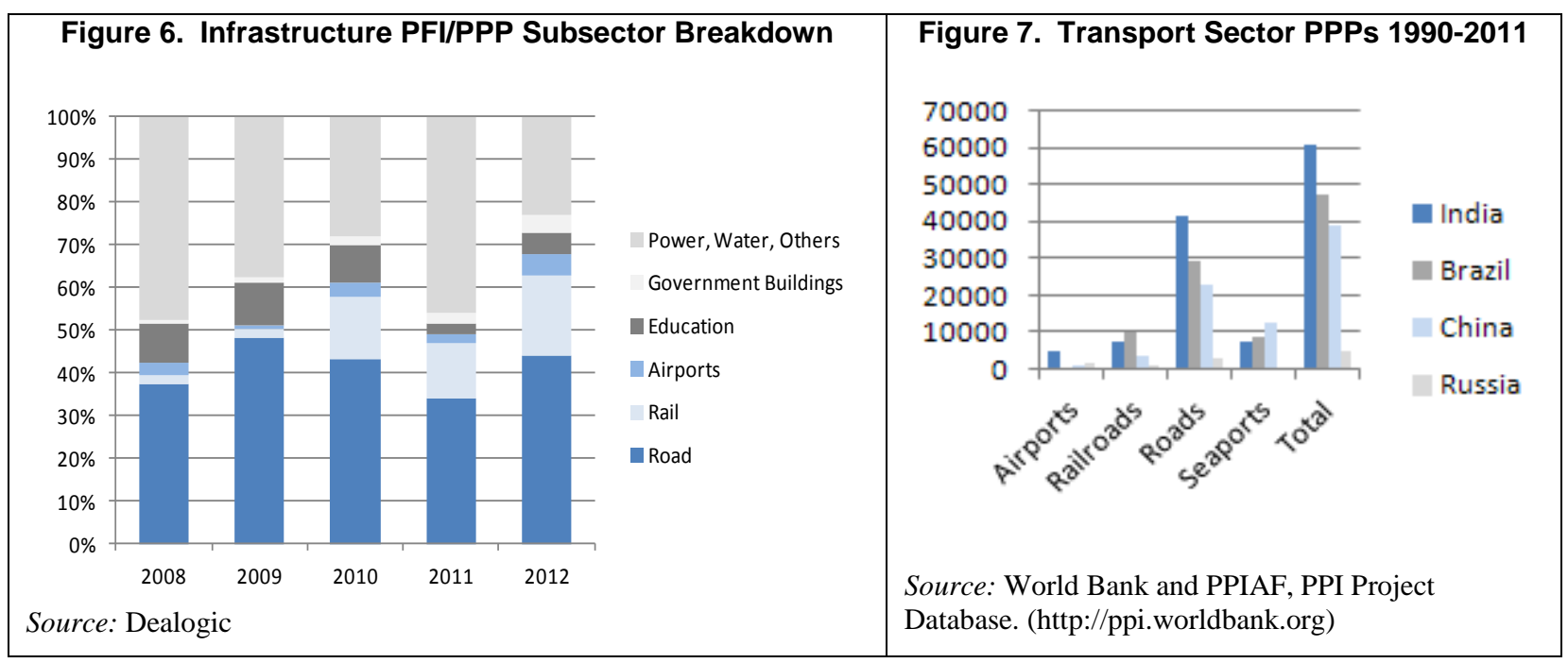

There are two main types of PPP, remunerated by tolls levied by the private partner or remunerated by availability payments from the government contracting agency. These entail rather different risks for the private parties and therefore tend to attract different types of investor. Transport projects also differ considerably in relation to risk, and demand risk in particular. Both types of PPP create liabilities for the taxpayer which need to be contained by transparent public accounting rules and budget procedures that identify them as on-balance sheet commitments.

Availability payments represent a lower risk for investors and attract bank loans with accompanying insurance and hedging instruments. Tolled facilities tend to require larger equity investment, at higher cost. Many availability payment based projects involve only "pinpoint equity", i.e. a very small equity holding, sometimes less than $1 \%$ of project finance.

Even availability payment based PPPs require extensive risk appraisal by investors, limiting their appeal to specialized investment banks and a few capital market funds. Regulated utility based models for investment attract a larger range of investors. They are a more familiar class of asset, with returns determined in relation to investment by a regulatory formula often linked to inflation ${ }^{17}$ and providing a return on investment from day one without the delay during the construction phase of a PPP. Many European airports are financed this way, so is rail infrastructure in Great Britain. An independent regulator is required in this model to arbitrate between the interests of investors, government and the users of the infrastructure. The regulator sets quality standards and user charges, subject to periodic review that provides a useful degree of flexibility in the context of long-term concessions under which contracts (including for PPPs) are inevitably incomplete.

Securitization provides an intermediate class of investment attracting an intermediate range of investors. This happens when the special purpose enterprise developing a PPP sells on the project at the point where construction is complete. In some jurisdictions the degree of securitization is subject to limits to preserve the efficiency benefits that can be potentially achieved through bundling construction with facility operation in a PPP

\footnotetext{
${ }^{16}$ Prepared by the International Transport Forum, an intergovernmental organisation with $\mathbf{5 4}$ member countries, with Secretariat at the OECD in Paris http://www.internationaltransportforum.org/ , See Better Regulation of PPPs for Transport Infrastructure OECD 2013

${ }^{17}$ Typically of the form RPI-X where X incentivizes efficiency.
} 


\subsection{Traditional Sources of Infrastructure Financing}

\section{Source of Capital - Debt}

Historically the large majority of project financing debt globally has been funded by banks. But with weakness and deleveraging in advanced economy financial sectors (particularly in Europe) likely to persist into the medium term, there is a growing mismatch between the amount and time horizon of available capital and that of infrastructure projects, particularly in EMDEs ${ }^{18}$. The emerging infrastructure financing gap is major policy concern that deserves further scrutiny (see Box 2).

\section{Box 2. Infrastructure financing gap}

The OECD estimates global infrastructure requirements to 2030 to be in the order of US\$ 50 tn. The International Energy Agency also estimated that adapting to and mitigating the effects of climate change over the next 40 years to 2050 will require around USD 45 tn or around USD 1tn a year. ${ }^{19}$

Such levels of investment cannot be financed by traditional sources of public finance alone. The impact of the financial crisis exacerbated the situation further reducing the scope for public investment in infrastructure within government budgets. The result has been a widespread recognition of a significant infrastructure gap and the need to greater recourse to private sector finance.

A further consequence of the crisis was the disappearance of some significant actors active in the infrastructure market such as monoline insurers ${ }^{20}$ in the capital markets. At the same time traditional sources of private capital such as banks, have restrained credit growth and may be further constrained in the coming years when new regulations (e.g. Basel III) take effect.

Many EMDEs also depend on foreign financial institutions (particularly banks) in order to finance investments in infrastructure. The emerging infrastructure financing gap therefore has the potential to be a source of ongoing vulnerability and growth dampener in these countries. A possible offset to the decline in long-term financing from European banks is the growth in financing from local banks based in EMDE economies as well as from foreign banks from other EMDEs. For instance, Chinese banks have been rapidly expanding their financing operations for infrastructure projects in EMDEs, particularly in Africa

Institutional Investors such as pension funds may therefore become significant in bridging the infrastructure gap as they invest more in infrastructure. Currently less than $1 \%$ of pension fund assets are allocated directly to such infrastructure projects, and obstacles (related to the nature of infrastructure investments - see section 6.3 , and to financing vehicles) remain.

Constraints on bank debt levels following the banking crisis and the disappearance of monolines in the capital market have negatively impacted infrastructure markets. As a consequence, deal volumes in 2012 were at an historic low, despite the closing of large transactions with governments' support. The

${ }^{18}$ European banks being more reliant on wholesale funding are under particular pressure

${ }^{19}$ See International Energy Agency (IEA) (2008), 'Energy Technology Perspectives: Scenarios and Strategies to 2050'. The estimate is that around half the investment will involve replacing conventional technologies with low-carbon alternatives with the remainder being additional investment.

${ }^{20}$ Monoline insurers are financial institutions focused solely on insuring bond issuers such as municipal governments against default. Bond issuers buy this insurance to upgrade the credit worthiness of their bonds, making the overall cost lower by giving confidence that the insured security would be paid in full. The first monolines were set up in the US in the 1970s, covering municipal and corporate bond issues. The financial crisis hit hard the monolines. Some lacked sufficient capital to cover their liabilities adequately. Several had their credit ratings reduced, effectively downgrading them to junk status. 
number of projects to reach financial close fell 8\% to 901 in 2012, down from 976 in 2011 and the first annual decline since 2002 (down $17 \%$ to 258 projects).

Global Project Finance stood at $\$ 382.3 \mathrm{bn}$ in 2012, a 6\% decrease from the $\$ 406.5 \mathrm{bn}$ recorded in 2011. Asia Pacific accounted for 50\% of global project finance in 2012. EMEA's share was $26 \%$ while the Americas made up 24\%. Since 2007, Asia Pacific's share of global project finance has increased (from a $19 \%$ share) while EMEA's has decreased (from a 56\% share). Americas' portion has increased steadily since 2010 (see Figures 8 and 9).

After the crisis European banks accounting in the past for the largest share of the global market in this sector, have significantly scaled back new lending. European volume continued to weaken and stood at $\$ 63.5$ bn in 2012, down 38\% from $2011(\$ 102.9 b n)^{21}$

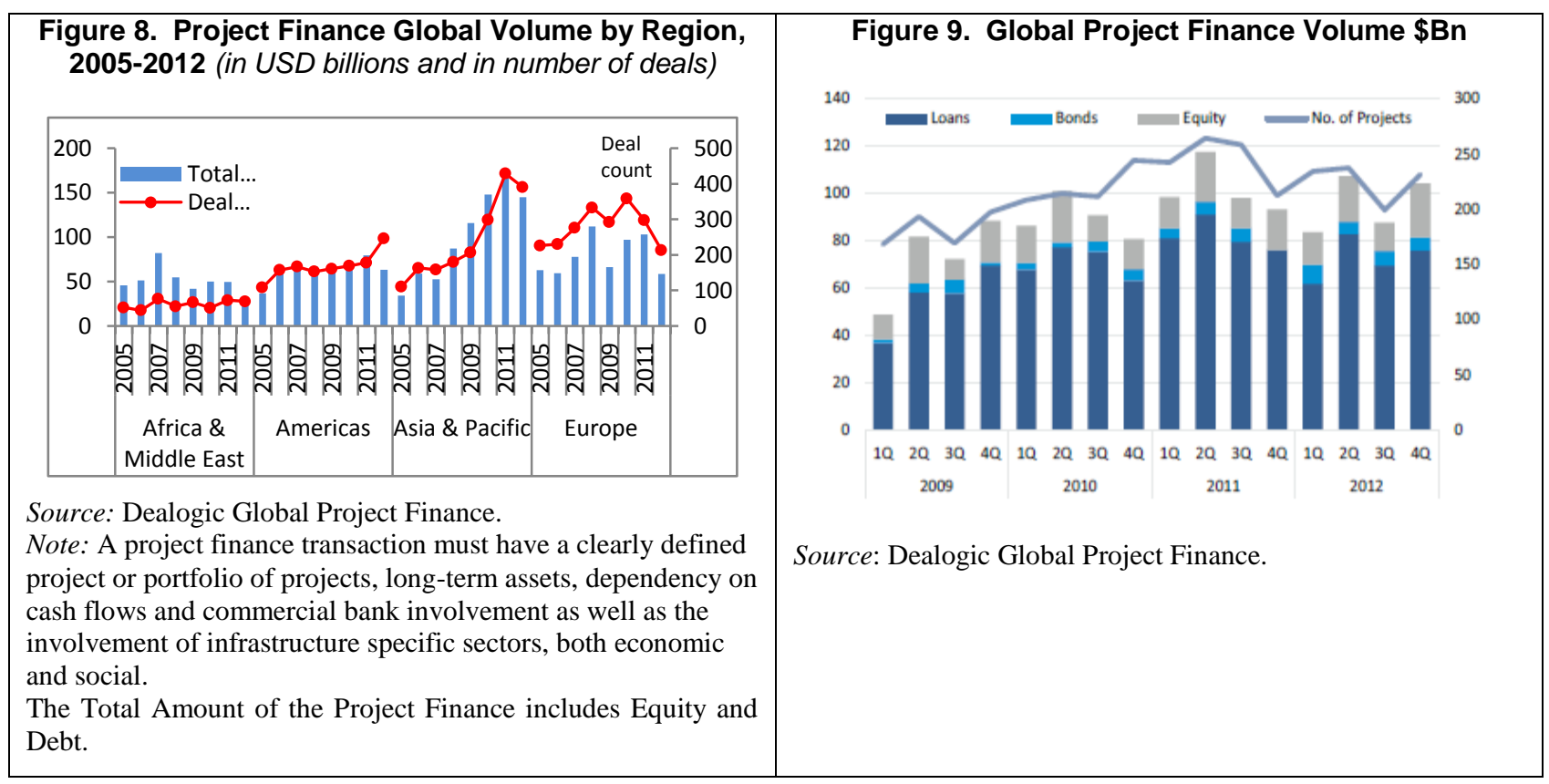

The demise of monolines has also impacted the capital markets for infrastructure, depriving the infrastructure market of a limited but valuable source of financing, especially in Europe. This was important in particular for institutional investors who lack the appetite for the diversity of project risks and do not have the specialist expertise required to appraise and monitor projects

While bond finance by corporations in infrastructure sectors reached a record level- with many corporations using the bond market to re-finance existing debt at more attractive rates - bond finance in new projects has come to a halt as a result of the financial crisis ${ }^{22}$

\footnotetext{
${ }^{21}$ After reaching a record $\$ 327.2 \mathrm{bn}$ in 2011 , loan volume decreased $12 \%$ to $\$ 289.4 \mathrm{bn}$ in 2012 . This was the first decline in project finance loan volume since 2009 when loan volume was $\$ 221.7 \mathrm{bn}$. Some of the most active banks in the infrastructure sector have largely withdrawn from the market (i.e. Depfa and more recently Espírito Santo Bank, Commerzbank and the large French Banks) due essentially to liquidity issues, or if rescued by national governments are now forced to focus on domestic countries onlay.

${ }^{22}$ Except in the case of low risk projects, infrastructure project bonds are rarely attractive to a broad investor base. One way to raise the attractiveness of project bonds has been to obtain insurance from specialist insurers known as monolines. In the UK, more than $50 \%$ of UK Private Finance Initiative projects with a funding requirement exceeding $£ 200 \mathrm{mn}$ used such "wrapped
} 
Another factor limiting the willingness of banks to lend long-term is that many banks active in project financing, have loans - a legacy of pre-crisis over-pricing - sitting on their books, which are difficult to refinance. Until recently it has not been possible to sell these loans in the secondary market without offering a big discount.

Before the credit crunch, project finance banks could free up regulatory capital using synthetic collateralised debt obligations ("CDO") that shifted credit risk from their balance sheets. This is now more difficult because of the collapse of both the monolines and investors' appetite for CDOs.

In the coming years there will be a huge volume of loans in need of refinancing to come to the market. The absence of an efficient capital market for infrastructure would represent a barrier to the financing of new projects (e.g. impeding recycling of capital).

\section{Source of Capital - Equity}

With the collapse of Lehman Brothers in September 2008 the fundraising market in all areas of illiquid alternatives declined and the infrastructure sector was also affected. However, fundraising recovered significantly in $2010^{23}$. Despite this growth in 2011 and 2012 activity was still some way off the returning pre-crisis levels.

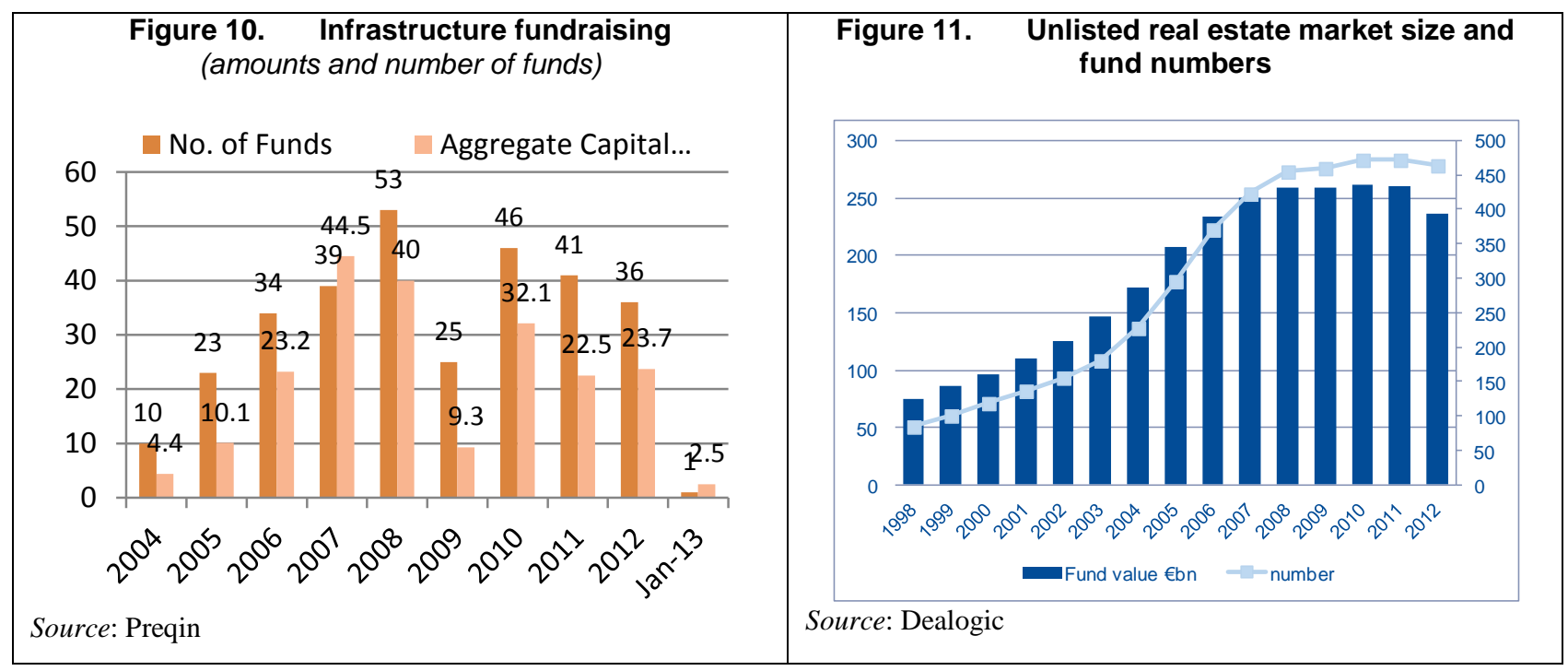

According to several sources at the moment, there is still a surplus of equity capital available for investment compared to the low number of infrastructure transactions in the market ${ }^{24}$. Large amounts of equity capital that have been allocated to the infrastructure asset class in fact remain un-invested. This

bonds" funded in the GBP capital markets. However, with the demise of the monoline business model in the wake of the crisis, such issuance practically came to a halt and the volumes of project bond issues generally have declined. Source EPEC (2010): Capital Markets in PPP financing - Where we were and where are we going? European Investment Bank.

${ }^{23} 2010$ infrastructure fundraising did recover significantly, however this was mainly due to a number of sizeable funds closing in 2010 which had been raising for up to three years. Much of the capital raised was actually secured pre-crisis with little actually committed in 2010 .

${ }^{24}$ According to Preqin, as of January 2013 there are 137 unlisted infrastructure vehicles in the market targeting $\$ 80$ bn in capital commitments. 
could be explained by a combination of factors which vary depending on regions and sub-sectors, including high returns thresholds for a given risk-level and the uncertain regulatory framework ${ }^{25}$.

However the availability of equity could be impaired in the long term. Traditional providers of equity to PPP projects such as construction and contracting companies, have become reluctant to invest and less able to hold the investments for the longer term.

Also, due to the lack of debt, many deals in the future will be more dependent on increased equity ratios with sponsors likely to shoulder more risk.

\section{Corporate Financing of Infrastructure}

Like other corporate peers, infrastructure companies have been rebuilding their cash reserves. However, they seem to have weathered the crisis better than other large companies (see Box 2).

The infrastructure sector has also faced major upheavals in its financing, composition and modes of operations. For instance, compared to five years ago, according to UNCTAD, there are comparatively more Transnational Corporations TNCs from the developing and transition economies in the list of top TNCs. TNCs from developed countries tend to have much larger assets as compared to TNCs from developing countries. But the number and importance of infrastructure TNCs from developing countries is rising and with a wide geographical spread by origin (main infrastructure TNCs from the South originate from Hong Kong, India, the UAE, Turkey, Singapore, Russia and Malaysia. Secondly, because infrastructure projects are high risks, long gestation period and of high capital intensity, TNCs enter countries using a variety of modes, either as sole investors, or via special purpose vehicles or consortiums in cooperation with other investors. This reflects the ability of private sector firm to engage in a variety of modes of operation to minimize the level of capital investment by one single partner and spread risk.

\footnotetext{
${ }^{25}$ Although some discuss the "quality" of available equity. Equity might be very abundant for brownfield private equity type of transactions. However, to finance new projects, long term equity assuming construction risk remains rare (on big projects in Europe with a very long construction period for instance, a few actors are present).
} 


\section{Box 3. Cash holdings of infrastructure TNCs}

Following a general trend observed globally, the largest 100 Transnational Corporations (TNCs) in the infrastructure sector also increased their cash holdings in recent years (figure below). Compared with their 2008 levels, cash and short-term investments rose by one fourth, to reach a peak of $\$ 316$ billion in 2011. However, infrastructure TNCs seems to have been better weathering the crisis with respect to the general trend for all TNCs. The ratio of their cash to total assets did not rise substantially in the aftermath of the crisis and went back to the 2006 level of 7.4\% after a slump during 2007-2009. This is different from what was witnessed for the largest global 100 TNCs; these experienced an increase in the ratio of their cash to total assets of about 1.5 percentage points.

Figure 12. Top 100 TNCs: cash holdings, 2005-2011

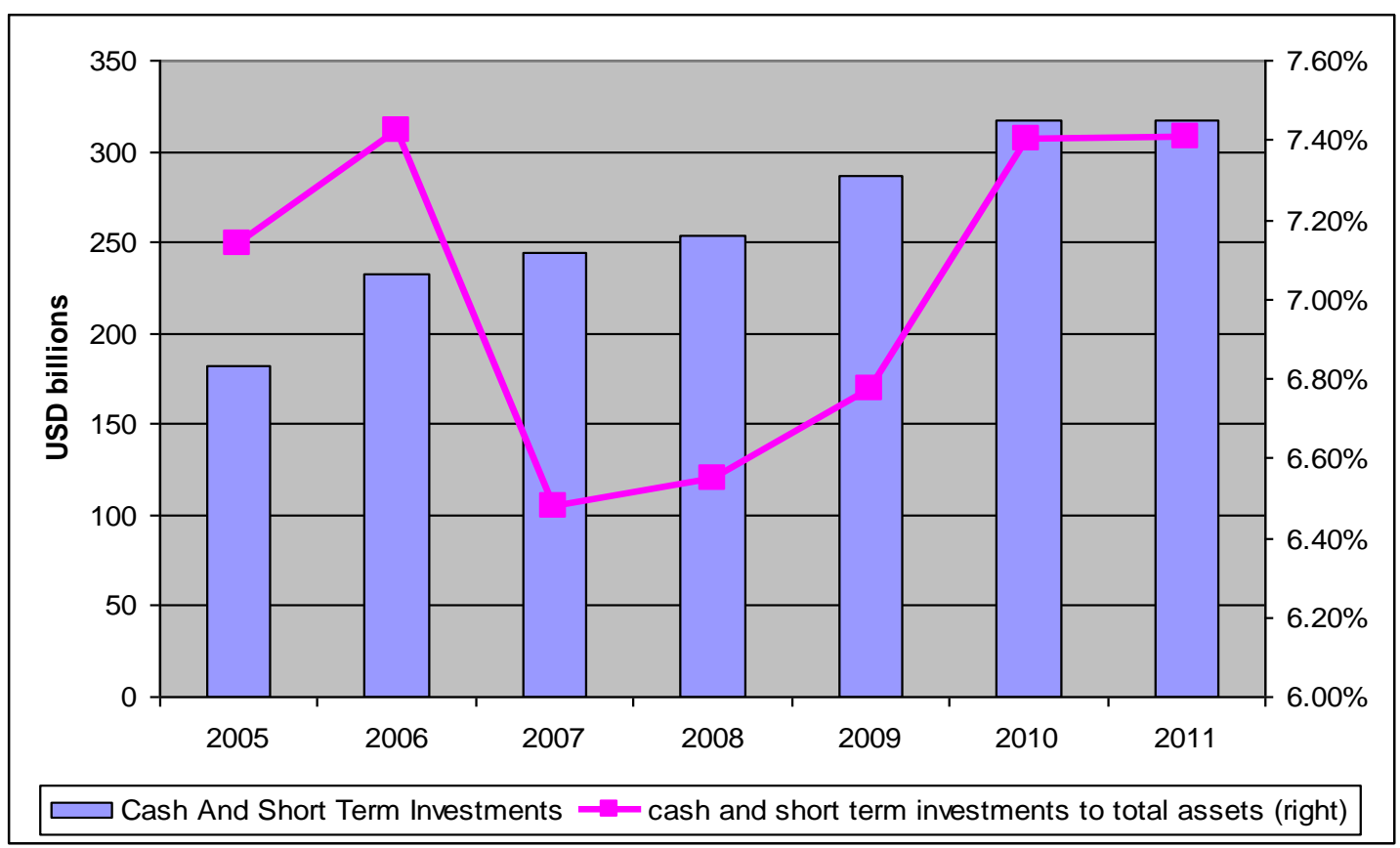

Source: UNCTAD

With the outbreak of the global financial crisis, corporations had to face tougher borrowing conditions. Over the next two years, the top 100 infrastructure TNCs faced a roughly $\$ 115$ billion hole in their cash flows as net issuance of debt fell from $\$ 98$ billion in 2008 to a net repayment of $\$ 16.7$ billion in 2010 . The need to compensate for reduced credit issuance and to spend cash on debt repayments required a significant build-up of liquidity levels.

To close the gap, infrastructure TNCs were forced to contemplate cutting dividends or investment expenditures. Given companies' extreme reluctance to cut their dividends for fear of seeing their stock price punished by the market, most infrastructure TNCs decided to slash their acquisitions activities. This translated into lower FDI flows in infrastructure after 2010 (see UNCTAD response to item 1a).

Summing up, cash holdings for this group of TNCs have been following a path imposed by necessity: in the aftermath of the crisis they increased to compensate for credit constraints and debt repayments. However, looking at the past levels of the cash to assets ratio it is hard to argue that cash holdings are in "excess".

Source: UNCTAD. 


\subsection{New Alternative Sources of Financing}

In recent years diversification benefits and higher expectations of investment returns are increasingly driving investors to alternative investments, such as private equity, real estate and commodities. Alternative investments generally have lower liquidity, sell in less efficient markets and require a longer time horizon than publicly traded stocks and bonds. Infrastructure is often included in the alternative investments part of the portfolios.

Institutional investors have traditionally invested in infrastructure through listed companies and fixed income instruments. This still remain the main exposure of institutional investors to the sector. It is only in the last two decades that investors have started to recognize infrastructure as a distinct asset class. Since listed infrastructure tends to move in line with broader market trends, it is a commonly held view that investing in unlisted infrastructure - although illiquid - can be beneficial for ensuring proper diversification. In principle, the long-term investment horizon of pension funds and other institutional investors should make them natural investors in less liquid, long-term assets such as infrastructure.

Infrastructure investments are attractive to institutional investors such as pension funds and insurers as they can assist with liability driven investments and provide duration hedging. These investments are expected to generate attractive yields in excess of those obtained in the fixed income market but with potentially higher volatility. Infrastructure projects are long term investments that could match the long duration of pensions liabilities. In addition infrastructure assets linked to inflation could hedge pension funds liability sensibility to increasing inflation.

However, although growing rapidly, institutional investment in infrastructure is still limited. In fact, currently pension fund investment in this more direct form of infrastructure investment represents around $1 \%$ of total assets on average across the $\mathrm{OECD}^{26}$. Different countries are at different stages in the evolution of pension fund investment in infrastructure. Some large pension funds, particularly in Australia and Canada, have been actively raising their allocation to infrastructure over the last decade and allocations are as high as $10-15 \%$ among some pension funds (see Table 2).

\footnotetext{
${ }^{26}$ Given the lack of official data at national level the OECD launched a survey on investments by selected pension funds across the world, that are among the largest in their respective country: the OECD Large Pension fund Survey 2011: If we consider total assets under management for the complete survey (i.e. 52 funds for USD 7.7 trillion AUM) direct infrastructure investment of USD 41.8 billion represented $0.5 \%$ of the total. See also Della Croce (2012) Trends in Large Pension Fund Investment in Infrastructure, Working Paper No 29 OECD
} 
Table 2. Large Pension Funds Infrastructure Investments

\begin{tabular}{|c|c|c|c|c|c|c|}
\hline \multirow[b]{2}{*}{ Name of the fund } & \multirow[b]{2}{*}{ Country } & \multirow{2}{*}{$\begin{array}{l}\text { Tot Assets } \\
\text { USD million }\end{array}$} & \multicolumn{4}{|c|}{ Infrastructure Investment $\%$ of total assets } \\
\hline & & & $\begin{array}{l}\text { Unlisted } \\
\text { Equity }\end{array}$ & $\begin{array}{l}\text { Listed } \\
\text { Equity }\end{array}$ & $\begin{array}{c}\text { Fixed } \\
\text { Income }\end{array}$ & Total \\
\hline ABP & Netherlands & 312,257 & 0.3 & n.a. & n.a. & 0.3 \\
\hline GEPF & South Africa & 138,572 & 0.1 & n.a. & 0.2 & 0.3 \\
\hline CPPIB & Canada & 136,039 & 6.0 & 0.8 & na & 6.8 \\
\hline PFZW & Netherlands & 131,780 & 2.0 & 0.0 & 0.0 & 2.0 \\
\hline OTPP & Canada & 101,655 & 7.0 & 0.7 & 1.6 & 9.3 \\
\hline Previ & Brasil & 88,847 & 0.0 & 13.5 & n.a. & 13.5 \\
\hline Future Fund & Australia & 65,824 & 4.1 & na & na & 4.1 \\
\hline OMERS & Canada & 52,385 & 15.5 & 0.0 & 0.0 & 15.5 \\
\hline PMT & Netherlands & 49,426 & 0.6 & n.a. & 0.0 & 0.6 \\
\hline Pension Reserve Fund & France & 49,033 & 0.0 & na & na & 0.0 \\
\hline USS & UK & 48,889 & 2.9 & n.a. & n.a. & 2.9 \\
\hline PFA & Denmark & 45,962 & 0.7 & n.a. & 0.0 & 0.7 \\
\hline AFP Provida Chile & Chile & 40,474 & 0.0 & 0.2 & 1.4 & 1.5 \\
\hline AustralianSuper & Australia & 33,800 & 11.5 & 0.2 & 0.1 & 11.8 \\
\hline AP-3 & Sweden & 30,661 & 0.5 & na & na & 0.5 \\
\hline AP-4 & Sweden & 29,560 & 0.0 & 9.0 & na & 9.0 \\
\hline UniSuper & Australia & 25,676 & 4.4 & n.a. & 0.0 & 4.4 \\
\hline Afore Bancomer Mexici & Mexico & 16,430 & 0.0 & 2.1 & 0.5 & 2.6 \\
\hline Sunsuper & Australia & 15,782 & 4.3 & n.a. & 0.2 & 4.5 \\
\hline Superannuation Fund & New Zealand & 11,162 & 3.3 & 6.6 & na & 9.9 \\
\hline AFP Horizonte-Col & Colombia & 7,930 & 1.7 & 7.5 & 2.4 & 11.5 \\
\hline COMETA & Italy & 7,484 & 0.0 & 2.2 & 1.5 & 3.7 \\
\hline Fonditel & Spain & 7,328 & 0.0 & n.a. & n.a. & 0.0 \\
\hline AFP Horizonte-Perú & Perú & 7,162 & 0.3 & 3.0 & 7.4 & 10.7 \\
\hline CAJA MADRID & Spain & 5,400 & 0.0 & 0.7 & 0.2 & 0.9 \\
\hline Fonchim & Italy & 3,915 & 0.0 & n.a. & n.a. & 0.0 \\
\hline Banco BPI & Portugal & 3,114 & 0.0 & 10.2 & 10.6 & 20.0 \\
\hline Endesa & Spain & 2,082 & 0.0 & 8.7 & 4.7 & 13.4 \\
\hline
\end{tabular}

Source: OECD Large Pension Funds Survey 2011

Data on SWF investment in infrastructure is not readily available but some funds report information on real estate investment, including infrastructure. As shown in Table 3, real estate and infrastructure allocations among some SWFs are relatively high, on the order of $10 \%$ or more in countries such as Singapore. Some funds, like the Norwegian Pension Fund - Global have also set target allocation substantially above their current allocation. 
Table 3. Selected SWF Real Estate Investments

\begin{tabular}{|l|l|c|}
\hline \multicolumn{1}{|c|}{ Country } & \multicolumn{1}{|c|}{ Sovereign Wealth Fund Name } & $\begin{array}{c}\text { As \% of } \\
\text { total }\end{array}$ \\
\hline Norway & Government Pension Fund - Global & $0,3 \%$ \\
\hline $\begin{array}{l}\text { UAE - Abu } \\
\text { Dhabi }\end{array}$ & Abu Dhabi Investment Authority & $5 \%-10 \%$ \\
\hline Saudi Arabia & SAMA Foreign Holdings & $1,2 \%$ \\
\hline Singapore & Government of Singapore Investment Corporation & $10,0 \%$ \\
\hline Singapore & Temasek Holdings & $12,0 \%$ \\
\hline South Korea & Korea Investment Corporation & $1,5 \%$ \\
\hline US - Alaska & Alaska Permanent Fund & $12,0 \%$ \\
\hline Azerbaijan & State Oil Fund & $0,0 \%$ \\
\hline US - Texas & Texas Permanent School Fund & $8,0 \%$ \\
\hline Ireland & National Pensions Reserve Fund & $6,0 \%$ \\
\hline New Zealand & New Zealand Superannuation Fund & $6,0 \%$ \\
\hline Canada & Alberta's Heritage Fund & 15,4 \\
\hline
\end{tabular}

Source: Annual reports of SWFs, SWF Institute

\section{Investing in “Green” Infrastructure}

As analysed in the G20/OECD note on Pension Fund Financing for Green Infrastructure, asset allocation by institutional investors into the types of direct investment which can help close the green infrastructure financing gap remains limited ${ }^{27}$.

Although 'green' investment is not specifically addressed in the investment policies of the majority of pension funds, and target allocations are seldom specified, some of the world's major pension funds have invested directly in clean energy projects. ${ }^{28}$ Some of the major insurance companies around the world have also made commitments to green infrastructure investment, and indeed have signalled their commitment to the sector through the development of a set of Principles for Responsible Insurance ${ }^{29}$.

\footnotetext{
${ }^{27}$ According to the Bloomberg New Energy Finance (BNEF) database, pension funds have invested in around 50 private equity funds that raised an estimated USD 21 billion in total between 2002 and 2010. In addition, at least 27 asset financing transactions (valued at approximately USD 12 billion between 2004 and 2011) and at least 12 Venture Capital and Private Equity deals (valued at USD 9 billion between 2002 and 2011) involved pension funds. In relation to insurance company investment in clean energy BNEF notes that insurance companies participated in 15 funds which raised a total of USD5.1 billion from 2001 to 2010.

${ }^{28}$ For more in depth analysis, the OECD reviews the role of institutional investors such as pension funds and insurance companies in clean energy in this report: Kaminker, C. and F. Stewart (2012), "The Role of Institutional Investors in Financing Clean Energy", OECD Working Papers on Finance, Insurance and Private Pensions, No. 23, OECD Publishing, Paris.

${ }^{29}$ Some - such as ATP in Denmark- have set up their own clean energy fund and are inviting other pension funds to join them. Others, (such as APG in the Netherlands and PensionDanmark) make their own direct project equity or debt investments or are investing in clean energy funds run by third parties. For example another major Dutch fund, PPGM, has committed capital to BNP Paribas Clean Energy Fund ${ }^{29}$. Some of the world's largest pension funds (including the pension plans for California's state teachers and public employees, CalSTERS and CalPERS) actively target clean energy projects via their ESG / SRI screenings and overlays as well as via direct investments.
} 


\section{Box 4. Examples of Insurance Companies' Investments in Clean Energy Projects}

Allianz: The German insurer aims to invest up to EUR 1.5 billion in renewable energy projects by 2012. As of March 2012 it has invested a total of EUR 1.3 billion in renewable energies, after buying three additional wind farms. Two of those are newly-built Nordex sites in France, which deliver around 22 megawatts, and one is in Germany with a capacity of 16 megawatts. At the start of 2011, Allianz's investments in wind and solar energy surpassed the EUR1 billion mark, and the company increased that amount by nearly $25 \%$ in the past 12 months. In total, Allianz now owns 34 wind farms with a total capacity of 658 megawatts and seven solar parks with a total capacity of 74 megawatts.

Aviva: The UK insurance company has exposure to green investment via several sources. First the parent insurance company (using its life insurance and annuities assets) has committed $1.5 \%$ of its assets to infrastructure investment. As well as gaining exposure to green assets via the Clean Tech fund, the company also invests directly in clean energy projects via its private equity investments. Aviva Investors, the asset management subsidiary of the parent insurance company, runs a European Renewable Energy fund of around EUR 250 million, investing in solar, biomass, biogas and wind projects. Returns are targeted at $12 \%$ IRR with yields of $10 \%$. The vehicle is Luxembourg regulated and specialized investment fund, structured as a SICAV and available to institutional investors. Money in this fund comes from both the parent insurance company's life insurance and annuities business, as well as from external clients (mostly pension funds). The fund will invest predominantly in greenfield projects but will also consider brownfield and secondary stage established assets.

Metlife: the US insurer has invested more than USD 2.2 billion in clean energy, and recently announced that it purchased a stake in Texas's largest photovoltaic project (a 30-megawatt plant with a contract to sell the output to Austin's municipal utility for 25 years). ${ }^{30}$

Munich Re: has announced plans to invest about EUR 2.5 billion in the next few years in renewable energy assets such as wind farms, solar projects and new electricity grids. ${ }^{31}$

Prudential: Prudential and its UK and European fund management arm, M\&G investments, have been investing in infrastructure for more than 80 years. One of the Prudential's first infrastructure investments was financing the hydroelecctric dam in Scotland in the 1930's (Carsfad Dam). Today Prudential is one of the leading managers of infrastructure assets through holdings in private debt and equity, as well as through corporate bonds and public equity investments. Infracapital is M\&G's infrastructure investment arm. Among its investments are solar and wind power projects and it is currently raising institutional capital for a third infrastructure investment fund.

Source: Kaminker, C. and F. Stewart (2012), "The Role of Institutional Investors in Financing Clean Energy", OECD Working Papers on Finance, Insurance and Private Pensions, No. 23, OECD Publishing, Paris

\footnotetext{
${ }^{30}$ See Bloomberg News 21/3/2012 'Solar 15\% Returns Lure Investments from Google to Buffett'

${ }^{31}$ According to an Associated Press report. AP cited Robert Pottmann, who is Head of Renewable Energy \& New Technologies (RENT) at Munich Ergo AssetManagement GmbH, Munich Re's asset management arm, in a wider report on German renewables.
} 


\section{Barriers to Investment}

While there is clearly growing interest among pension funds, insurers, SWFs and other institutional investors in infrastructure investments, major challenges remain before a substantial increase in allocations may occur. Among the several challenges the following may be highlighted:

- Lack of appropriate financing vehicles: only the largest investors have the capacity to invest directly in infrastructure projects. Collective investment vehicles have been available, such as infrastructure funds, but problems with high fees and extensive leverage mean that these have become less popular since the financial crisis ${ }^{32}$. Interesting vehicles to assist pension funds to invest in the infrastructure sector have been developed in some Latin American countries (such as Chile via infrastructure bonds with insurance guarantees, in Mexico via structured products and in Peru via a collective trust structure and in Brazil via a joint-owed infrastructure company.

- There is also a lack of debt instruments such as bonds for institutional investors to access infrastructure projects. This is notable since bonds remain the dominant asset class on average in portfolio allocations of insurers and pension funds across OECD countries (see section 4 of this note).

- Regulatory barriers: the move to market-consistent valuations and risk-based solvency standards is indirectly affecting the ability of pension funds and insurers to invest in infrastructure and other alternative asset classes. Specifically, when discount rates are based on market interest rates, there is a strong incentive to use bonds and interest rate hedging instruments to reduce volatility in solvency levels, as has been observed in the insurance sector.

- Inappropriate risk transfer: institutional investors generally have a preference for brownfield-type investments, which they see as less risky and more aligned with a long investment horizon. They also need access to both the equity and debt side of infrastructure deals with adequate safeguards against regulatory and commercial risks. At the same time, securitisation of infrastructure projects can weaken the incentives for efficient operation created by bundling construction, operation and maintenance, so some governments place limits on the share of projects that can be sold in this way. ${ }^{33}$

- Lack of objective, high quality data on infrastructure and a clear and agreed benchmark, making it difficult to assess the risk in these investments to understand correlations with other assets. This makes it difficult to assess the risks of these investments and to understand correlations with the investment returns of other assets. Without such information investors are reluctant to make such allocations.

- A related issue is that, whilst some countries collect data which matches the needs of the relevant authorities, there is no international, official, accurate data on the asset allocation of pension funds in alternative asset classes, which include, inter alia, hedge funds, private equity, real estate, infrastructure, and commodities. Infrastructure investing also typically involves the use of alternative investment products. The OECD has begun to collect such data and to make such comparisons.

\footnotetext{
${ }^{32}$ For example, industry sources suggest around USD $\$ 20-50$ billion of assets under management is required to justify building a management team. When such teams are formed, investors may prefer equity to generate the higher returns to justify the costs of the team.

${ }^{33}$ See Better Regulation of PPPs for Transport Infrastructure, International Transport Forum 2013
} 
- Challenges particular to 'green infrastructure': reasons for institutional investor hesitancy to invest directly in green infrastructure range from energy and environment regulatory and policy uncertainty to risks specific to new technology related projects making it difficult for rating agencies to give sufficient investment grade ratings. Capital along the clean energy project cycle is highly fragmented across equity and debt, and smaller scale deals or energy efficiency projects lack aggregation mechanisms. These issues are compounded by a lack of suitable investment vehicles (such as green bonds or funds) providing the liquidity and risk/return profile that institutional investors need. In addition, pension fund trustees, who are not environmental experts and indeed often non-financial specialists, remain cautious when it comes to increasing their exposure to newer clean technologies ${ }^{34}$.

\footnotetext{
${ }^{34}$ The OECD is currently examining lessons learned from a number of case studies of green investments around the world undertaken institutional investors. The case studies will examine whether the projects delivered the necessary risk adjusted returns to investors, and why. It will build on the policy messages delivered to G20 Leaders at Los Cabos in June 2012 on scaling up green investment by institutional investors, and draw more specific ideas for policy makers on policy design and how to structure deals in order to encourage investments from pension funds and other institutional investors into green projects. The analytical work will be published in the summer of 2013.
} 


\section{CONCLUSIONS}

The disruption to long term finance patterns is due to a mix of underlying problems which are in part a consequence of recent developments following the financial crisis and in part due to some more structural problems and longer term trends.

Institutional investors, such as pension funds, insurers and sovereign wealth funds due to the longer-term nature of their liabilities, represent potentially major source of long-term financing for illiquid assets such as infrastructure. Over the last decade, institutional investors have been looking for new sources of longterm, inflation protected returns. Asset allocation trends observed over the last years show a gradual globalization of portfolios with an increased interest in EMs and diversification in new asset classes.

The economic downturn is likely to have a lasting impact on the fund management industry and on long term asset allocation strategies of institutional investors. On one hand, in promoting more cautious investment strategies and a greater focus on portfolio risk management in the coming years. On the other hand, the prolonged low-yield environment has heightened the need for return-enhancing strategies, pushing some investors to invest in alternative assets. More fundamentally, the role of institutional investors in long term financing is constrained by the short-termism increasingly pervasive in capital markets as well as structural and policy barriers such as regulatory disincentives, lack of appropriate financing vehicles, limited investment and risk management expertise, transparency, viability issues and a lack of appropriate data and investment benchmarks for illiquid assets. In order to better understand the impact of these factors, more granular data at the level of individual investors is needed.

It is also necessary to better understand the extent to which institutional investors such as pension funds, insurers, SWFs and PPRFs may provide alternative or complementary sources of financing for infrastructure. As highlighted in the G20/OECD Policy Note: "Pension Fund Financing for Green Infrastructure Initiatives", investment in infrastructure by institutional investors is still limited due to, among other things: a lack of appropriate financing vehicles, investment and risk management expertise to deal with infrastructure investments, regulatory disincentives, lack of quality data on infrastructure, a clear and agreed investment benchmark and challenges particular to 'green infrastructure' (e.g., regulatory and policy uncertainty and inexperience with new technologies and asset classes)35. These challenges should be further examined with possible implications for the policy framework under which financial institutions operate. Ultimately, there is a need for further guidance promoting long-term investment by institutional investors to support policies that facilitate investments in infrastructure.

${ }^{35}$ G20/OECD Policy Note: "Pension Fund Financing for Green Infrastructure Initiatives" 


\section{APPENDIX 1. PENSION FUNDS AND INSURERS TO GDP RATIOS}

Figure 13. Countries with highest pension fund to GDP ratios among the reporting OECD and non-OECD countries, 2011

Total assets as a percentage of GDP

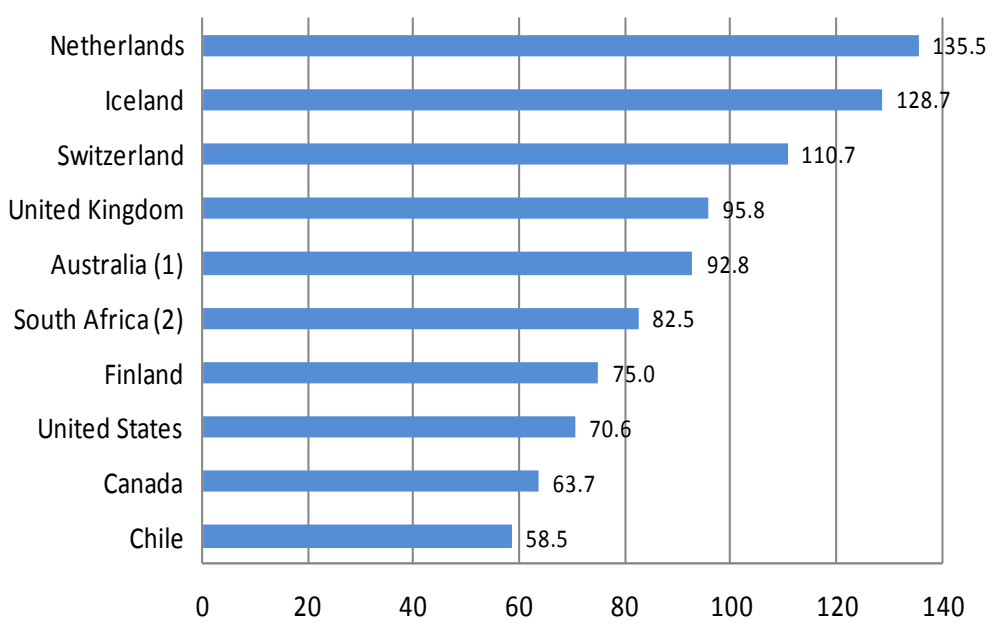

Source: OECD Global Pension Statistics.

Note: The top ten countries with the highest ratio among OECD countries and selected non-OECD countries included in the Global Pension Statistics exercise have been displayed in the Figure.

1. Data refer to the end of June 2011.

2. Data refer to 2010.

Figure 14. Countries with highest insurers to GDP ratios among the reporting OECD and non-OECD countries, 2011

Total assets as a percentage of GDP

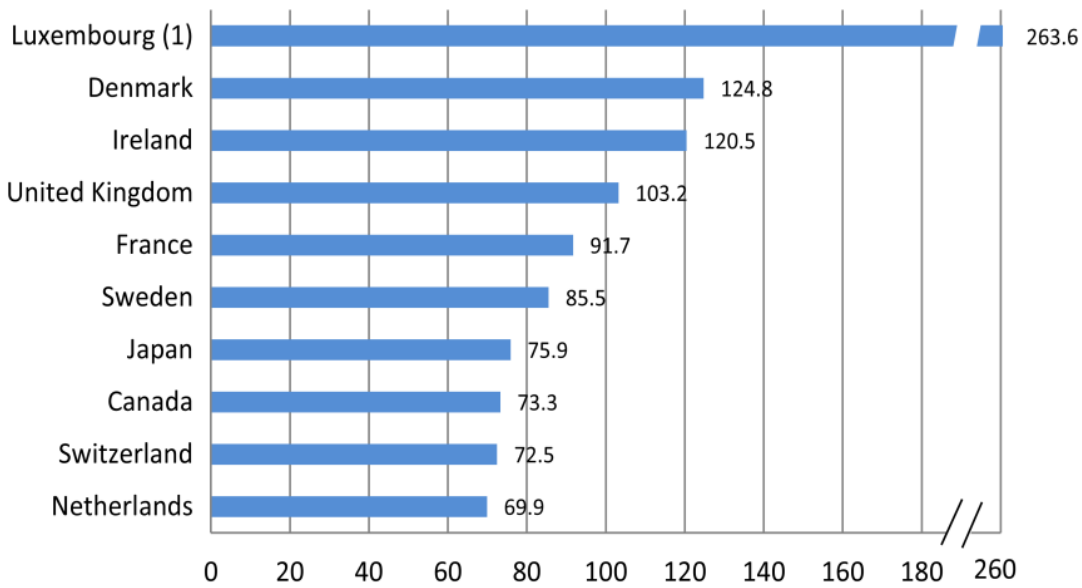

Source: OECD Global Insurance Statistics.

Note: The Top ten countries with the highest ratio among OECD countries and selected non-OECD countries (Hong Kong, India, Indonesia, Malaysia, the Russian Federation, Singapore, South Africa, Thailand) included in the Global Insurance Statistics exercise have been displayed in the Figure. Total assets from all direct insurers for all the sectors (life, non-life and composite) have been taken into consideration.

1. Data refer to 2010. 
Figure 15. Foreign investment of pension funds in selected OECD countries, 2011

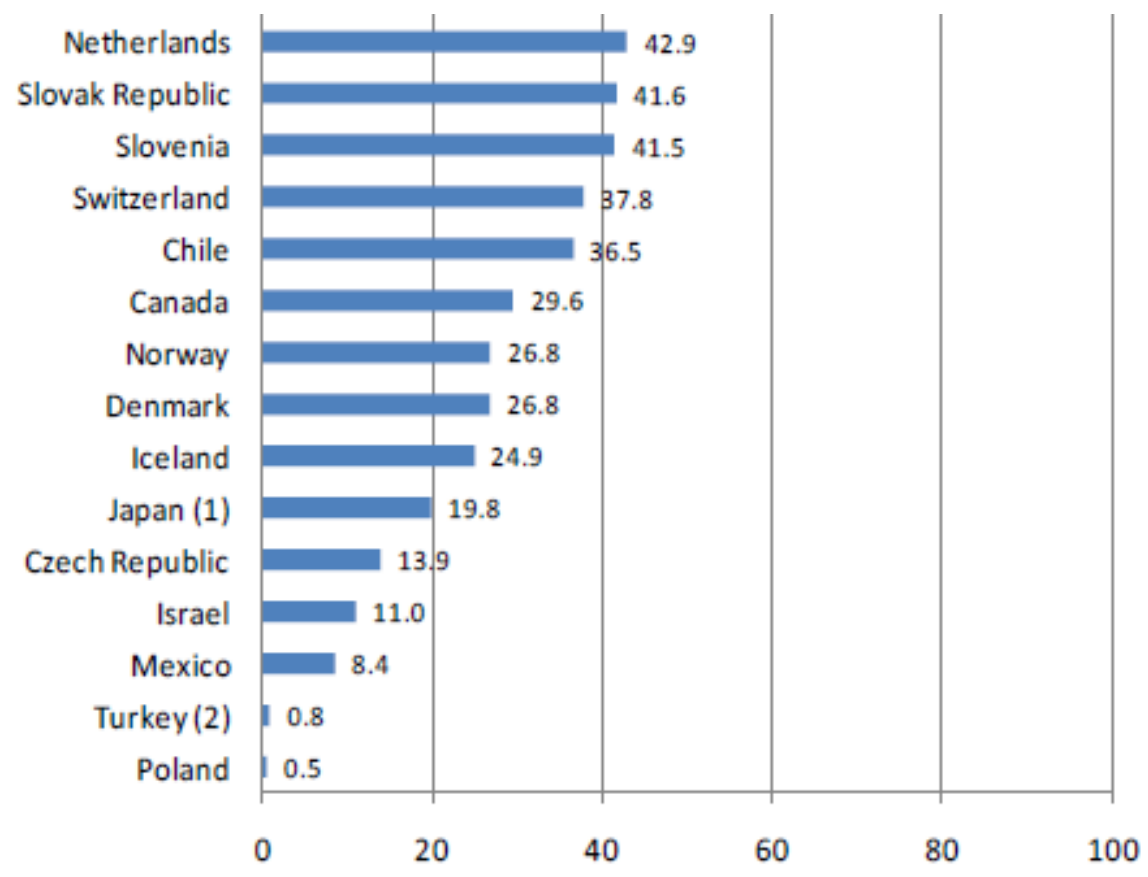

Source: OECD 
APPENDIX 2. CLEAN ENERGY ASSET FINANCING

Figure 16. Clean energy asset financing where pension funds (left) and insurance companies (right)

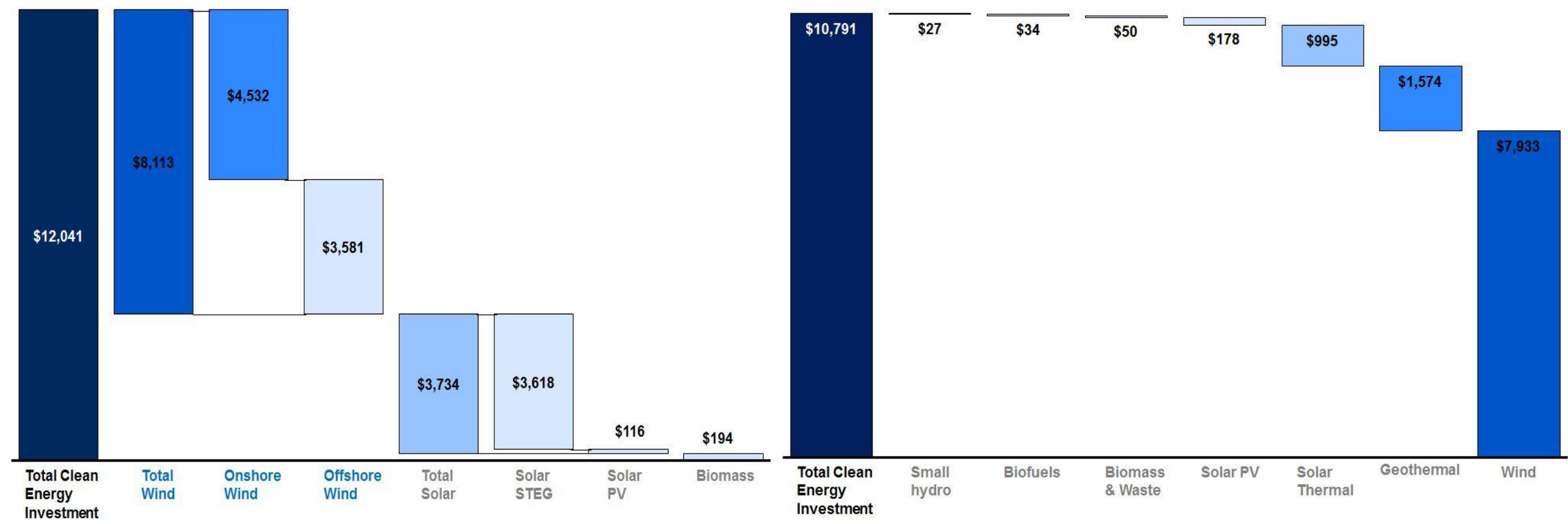

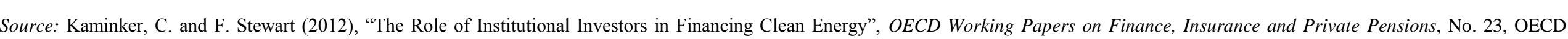
Publishing, Paris 


\section{WORKING PAPERS PUBLISHED TO DATE}

The full series is listed below in chronological order. Prior to March 2010, the series was named OECD Working Papers on Insurance and Private Pensions. All working papers can be accessed online at: www.oecd.org/daf/fin/wp.

WP 35 Institutional investors and green infrastructure investments: selected case studies

WP 34 Promoting Financial Inclusion through Financial Education

WP 33 Financial Education in Latin America and the Caribbean

WP 32 Pension Fund Investment in Infrastructure: A Comparison between Australia and Canada

WP 31 Policyholder Protection Schemes: Selected Considerations

WP 30 The Effect of Solvency Regulations and Accounting Standards on Long-Term Investing

WP 29 Trends in Large Pension Fund Investment in Infrastructure

WP 28: Communicating Pension Risk to DC Plan Members: The Chilean Case of a Pension Risk Simulator

WP 27: The Role of Funded Pensions in Retirement Income Systems: Issues for the Russian Federation

WP 26: Infrastructure Investment in New Markets: Challenges and Opportunities for Pension Funds

WP 25: The Status of Financial Education in Africa

WP 24: Defining and Measuring Green Investments: Implications for Institutional Investors' Asset Allocations

WP23: The Role of Institutional Investors in Financing Clean Energy

WP22: Defining and Measuring Green Investments: Implications for Institutional Investors' Asset Allocations

WP21: Identification and Assessment of Publicly Available Data Sources to Calculate Indicators of Private Pensions

WP20: Coverage of Private Pensions Systems: Evidence and Policy Options

WP19: Annual DC Pension Statements and the Communications Challenge

WP18: Lessons from National Pensions Communication Campaigns

WP17: Review of the Swedish National Pension Funds

WP16: Current Status of National Strategies for Financial Education

WP15: Measuring Financial Literacy: Results of the OECD International Network on Financial Education (INFE) Pilot Study 
WP14: Empowering Women through Financial Awareness and Education

WP13: Pension Fund Investment in Infrastructure: Policy Actions

WP12: Designing Optimal Risk Mitigation and Risk Transfer Mechanisms to Improve the Management of Earthquake Risk in Chile

WP11: The Role of Guarantees in Defined Contribution Pensions

WP10: The Role of Pension Funds in Financing Green Growth Initiatives

WP9: Catastrophe Financing for Governments

WP8: Funding in Public Sector Pension Plans - International Evidence

WP7: Reform on Pension Fund Governance and Management: The 1998 Reform of Korea National Pension Fund

WP6: Options to Improve the Governance and Investment of Japan's Government Pension Investment Fund

WP5: The New IAS 19 Exposure Draft

WP4: The EU Stress Test and Sovereign Debt Exposures

WP3: The Impact of the Financial Crisis on Defined Benefit Plans and the Need for CounterCyclica Funding Regulations

WP2: Assessing Default Investment Strategies in Defined Contribution Pension Plans

WP1: Framework for the Development of Financial Literacy Baseline Surveys: A First International Comparative Analysis

\section{OECD Working Papers on Insurance and Private Pensions}

WP41: Policy Action in Private Occupational Pensions in Japan since the Economic Crisis of the 1990s

WP40: Pension Funds' Risk-management Framework: Regulation and Supervisory Oversight

WP38: Managing Investment Risk in Defined Benefit Pension Funds

WP37: Investment Regulations and Defined Contribution Pensions

WP36: Private Pensions and Policy Responses to the Financial and Economic Crisis

WP35: Defined-contribution (DC) arrangements in Anglo-Saxon Countries

WP34: Evaluating the Design of Private Pension Plans

WP33: Licensing Regulation and the Supervisory Structure of Private Pensions

WP32: Pension Fund Investment in Infrastructure 
WP31: Pension Coverage and Informal Sector Workers

WP30: Pensions in Africa

WP29: Ageing and the Payout Phase of Pensions, Annuities and Financial Markets

WP27: Fees in Individual Account Pension Systems

WP26: Forms of Benefit Payment at Retirement

WP25: Policy Options for the Payout Phase

WP24: National Annuity Markets

WP23: Accounting for Defined Benefit Plans

WP22: Description of Private Pension Systems

WP21: Comparing Aggregate Investment Returns in Privately Managed Pension Funds

WP20: Pension Fund Performance

WP19: Coverage of Funded Pension Plans

WP18: Pension Fund Governance

WP17: Funding Regulations and Risk Sharing

WP16: Evaluating the Impact of Risk Based Funding Requirements on Pension Funds

WP15: Governance and Investment of Public Pension Reserve Funds in Selected OECD Countries

WP14: Sovereign Wealth and Pension Fund Issues

WP13: Reforming the Valuation and Funding of Pension Promises

WP12: Pension Fund Investment in Hedge Funds

WP11: Implications of Behavioural Economics for Mandatory Individual Account Pension Systems

WP10: Portfolio Investment in an Intertemporal Setting

WP9: Collective Pension Funds

WP8: Pension Fund Regulation and Risk Management

WP7: Survey of Investment Choice by Pension Fund Members

WP6: Benefit Protection

WP5: Benefit Security Pension Fund Guarantee Schemes

WP4: Governments and the Market for Longevity-Indexed Bonds

WP3: Longevity Risk and Private Pensions

WP2: Policy Issues for Developing Annuities Markets

WP1: Funding Rules and Actuarial Methods 